\title{
Muri/effetti collaterali
}

\author{
Alessandra Cirafici
}

Abstract

II contributo, a partire dalla considerazione che il bisogno di 'connettere' è tanto più forte quanto più pervasiva si manifesta la tendenza a 'separare' e a costruire barriere, proverà a proporre qualche considerazione sulla potenza della rappresentazione e sulla sua capacità di costruire ponti reali o ideali tra le idee, le parole e le cose, oltrepassando come suggerisce la call "con la forza della provocazione, il semplice pensiero razionale". In particolare il tema delle barriere fisiche o virtuali, intese come luoghi di conflitto tra popoli e culture troverà, il suo caso esemplare nel muro evocato a gran voce dalla amministrazione Trump sul confine tra USA e Messico. Metafora per eccellenza del tema evocato, si proverà a descriverne i contorni a partire dalla narrazione mediatica, sino alla proposta di un progetto-manifesto che, rispondendo al bando emanato dagli USA, ne sconfigge i presupposti utilizzando la rappresentazione, nella sua accezione di acceleratore del pensiero progettuale, in un processo di interpretazione critica della realtà che tiene insieme spazio e società.

Parole chiave

muro, conflitto, architettura militante, rappresentazione, narrazione.

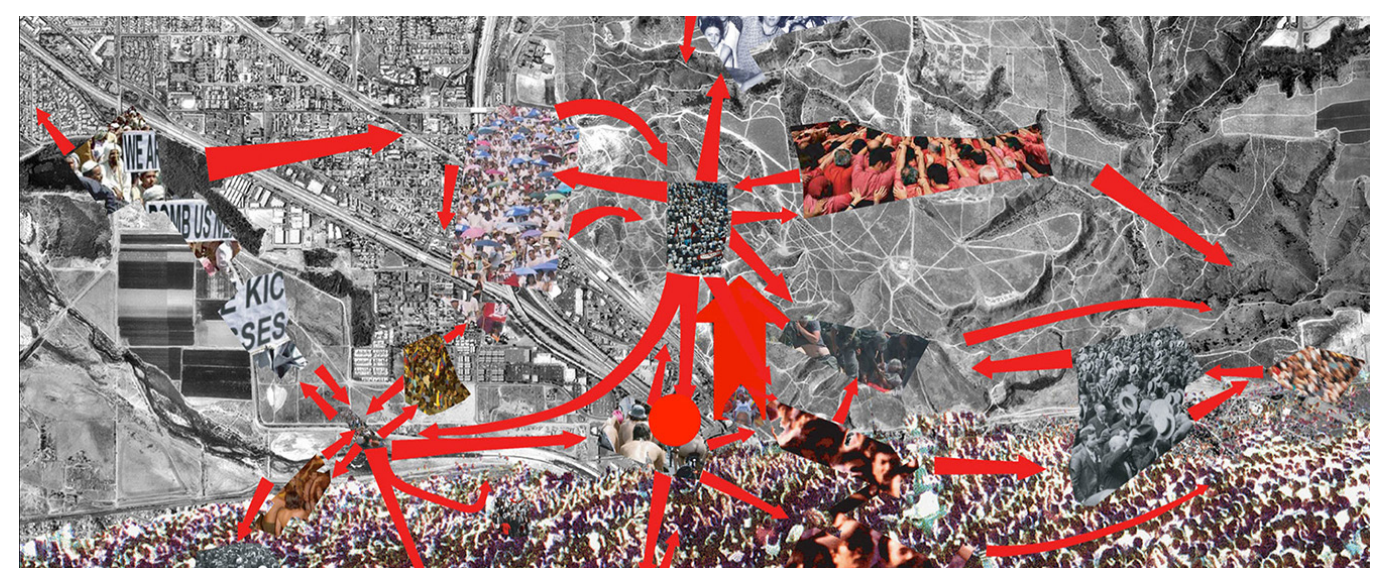


"Cosa vuol dire che l'architettura è un'arma politica? Per rispondere a questa domanda, abbiamo bisogno di vedere come l'architettura, in primo momento, è un'arma (e cioè, come l'architettura abbia la propensione per la violenza) $\mathrm{e}$ in secondo momento, come questa propensione è necessariamente strumentalizzata da una o diverse agende politiche" [Lambert 2013, p. 59]

Le considerazioni che seguono si sviluppano mettendo alla prova gli strumenti della rappresentazione e della progettazione dell'architettura, come ambiti di possibile interpretazione critica dello spazio dell'abitare. Uno spazio in continuo divenire, inteso come spazio di relazioni e connessioni, di interferenze e di conflitti. In questo orizzonte critico, la rappresentazione smette di interpretare il ruolo esclusivamente descrittivo del reale per assumere invece quello di potente narratore della sua complessità e dunque di attivatore di immaginazione e di pensiero critico, lavorando in perfetta sintonia con le logiche del progetto di cui si rivela essere parte integrante. C'è di più, la rappresentazione così intesa si mostra come strumento critico, di interpretazione, di discretizzazione, di arbitraria ma consapevole riduzione della complessità, negli elementi di una sintesi visiva che è in sé atto progettuale, il cui esito è innanzitutto quello di decodificare la sintassi degli elementi dell'esistente, talvolta di prospettarne una nuova che sia capace di tenere in conto le ragioni e le tensioni di uno spazio urbano inteso, come 'spazio di vita' in cui progettare nuove attribuzioni di senso. Un'opera di 'disvelamento' della realtà che interpreta il significato più vero del 'rappresentare'.

In una simile prospettiva l'aspetto comunicativo del rappresentare prende il sopravvento rendendo possibile l'allestimento di veri e propri 'manifesti' in cui il pensiero critico trova forme espressive e diventa potenzialmente progetto. Parallelamente, come in epoche passate di mobilitazione e di militanza, il progetto stesso è manifesto, esasperazione di aspetti scelti della realtà, portati alle estreme conseguenze in prefigurazioni di mondi possibili, auspicabili o terribili, presenti 'in nuce' nel mondo che abitiamo.

La possibilità di utilizzare il pensiero progettuale come potente detonatore di denuncia sociale attraverso un raffinato lavoro intellettuale, tutto giocato sul confine tra realtà e immaginazione e incentrato sul tema rovente dei 'confini' fisici, materiali e/o immateriali, che costellano il nostro mondo, ha rappresentato l'occasione del caso studio che qui si porta all'attenzione della nostra comunità scientifica.

Fig. I. Rem Koolhass, Exodus or the Voluntary Prisoners of Architecture London, UK | 1972 Rem Exhausted Fugitives Led to Reception Exodus, or the Voluntary Prisoners of Architecture, 1972

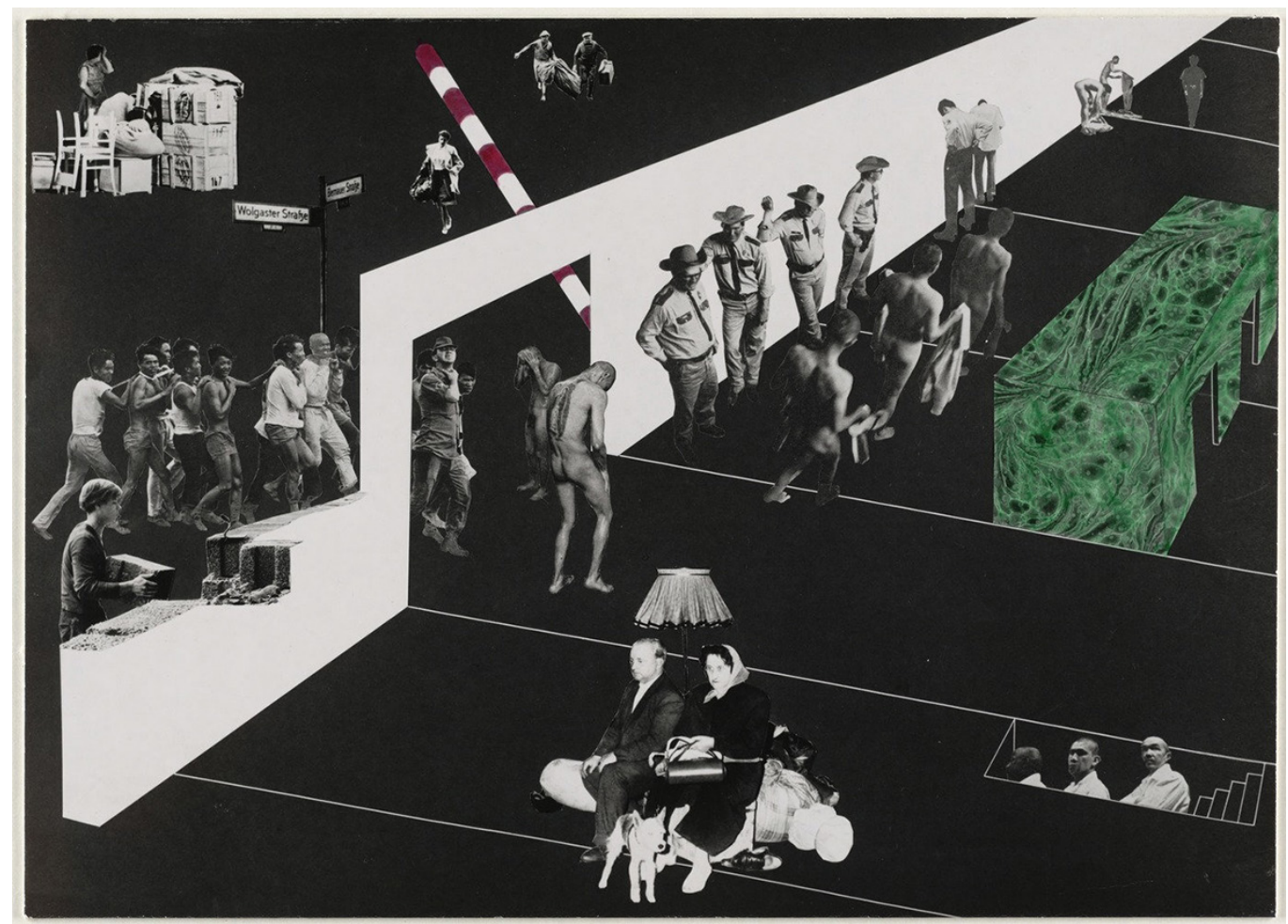


"La materia che chiamiamo muro e la materia che chiamiamo corpo sono entrambe situate spazialmente nel mondo in un particolare momento.

Per le loro proprietà fisiche, nessuno di questi due può occupare le stesse coordinate spaziali nello stesso momento. Questo vuol dire che per un corpo occupare le stesse coordinate spaziali di un muro, significa attraversarlo. Un conseguente shock si verifica per entrambi i corpi, e questo shock è quello che chiamiamo violenza. La prima dimensione politica attraverso la quale noi pensiamo a questo incontro tra il muro e l'uomo sta nel fatto che i muri sono sempre costruiti in un modo tale che l'energia del solo corpo e le sue forze (senza l'uso di strumentazioni) sia incapace di compromettere l'integrità del muro"

[Lambert 2013, p. 7I]

Qualche anno fa uno studente brillante e visionario - uno di quelli nel cui sguardo intenso ti capita a volte di ritrovare il senso e le ragioni per cui hai intrapreso questo viaggio - mi propose un tema per la sua tesi di laurea in Architettura davvero singolare: voleva partecipare alla "Solicitatio Number 20 I7-JC-RT-00 I" con cui il 24 febbraio 2017 I'Office U.S. Coustoms and Border protection del Department of Homeland Security richiedeva "Design and build of several prototype wall structure in the vicinatory of the United States border with Mexico" [I]. In poche parole Carmine, così si chiamava il mio studente, mi chiedeva seriamente di partecipare alla richiesta elettronica dell'amministrazione Trump di proporre idee e prototipi per la progettazione e la realizzazione di diverse strutture protettive nelle vicinanze del confine Messicano. L'appalto, condotto in due fasi, richiedeva di presentare, nella prima, un documento 'concettuale' entro il I 0 Marzo 20 I7. Poco più di due settimane per un progetto che avrebbe dovuto occupare una porzione di territorio di circa 3000 chilometri. Ci misi un attimo per capire la portata della provocazione e accettai la sfida. Chiesi innanzitutto a Carmine di costruire una documentazione dettagliata del percorso con cui l'idea del muro si era andata formalizzando nella mente di Trump ed era, poi, stata veicolata nella opinione pubblica americana. (fig. 2) Ne venne fuori un documento di straordinario interesse in cui la rappresentazione dell'idea del muro di Trump faceva da sfondo ad una narrazione assai articolata sul tema dei 'dispositivi di controllo fisico' e dei 'dispositivi di separazione attiva' che ben oltre il singolo episodio in questione erano presenti a livello mondiale (fig. 3).

Fig. 2. Cronistoria della zione dellidea comunicazion USA ldea del muro tra USA e Mexico dalle prime dichiarazioni sino bando nel febbraio 2017 .

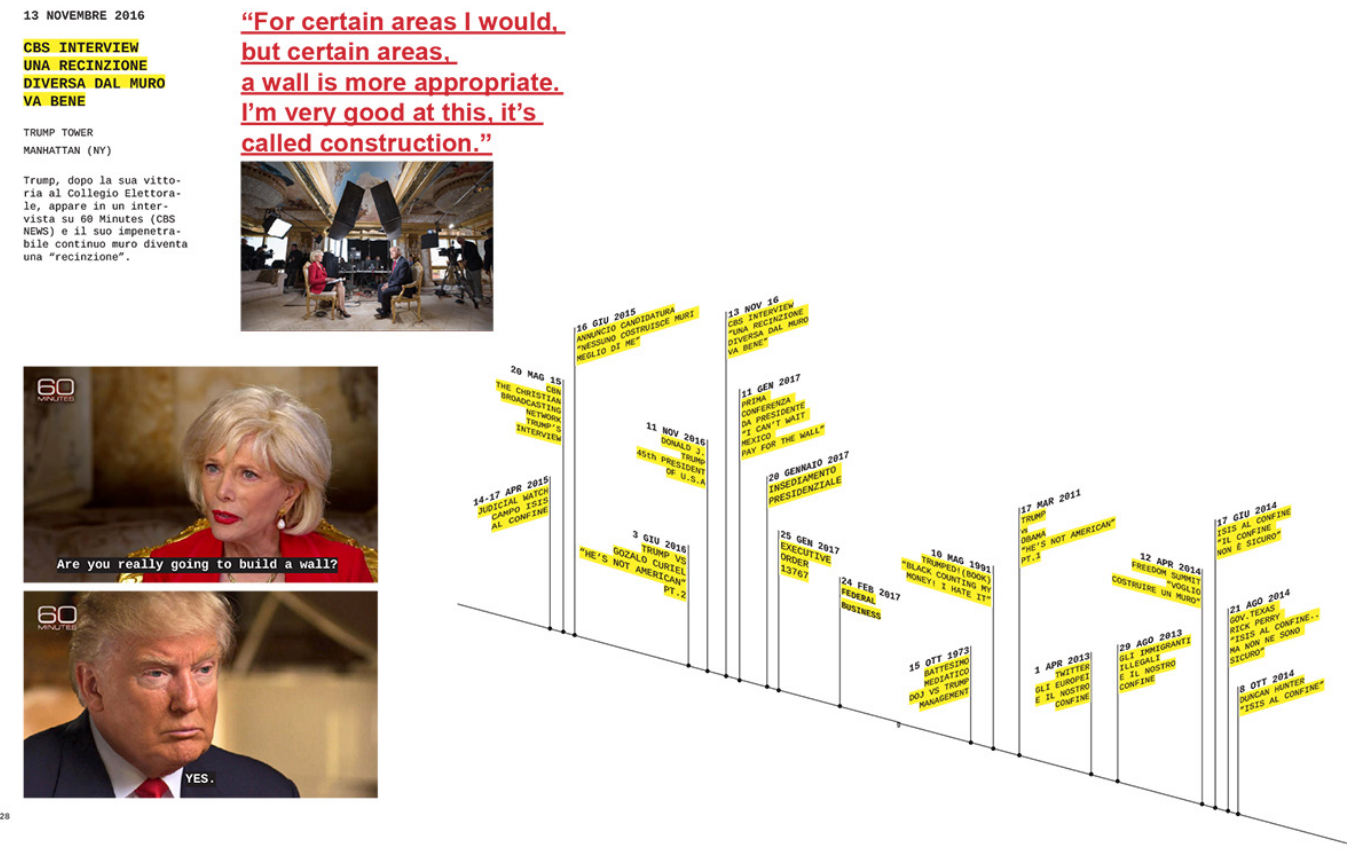


II termine 'dispositivo' non è scelto a caso, ma rispecchia perfettamente l'accezione di Michel Foucault che per dispositivo intende "un insieme assolutamente eterogeneo che implica discorsi, istituzioni, strutture architettoniche, decisioni regolative, leggi, misure amministrative, enunciati scientifici, proposizioni filosofiche, morali e filantropiche", sicché declinato nell'ambito specifico del controllo dei confini, il concetto di dispositivo finisce con l'essere perfettamente calzante con un'idea di "funzione strategica dominante [...] manipolazione di rapporti di forze, e intervento razionale e concertato in questi rapporti di forze, sia per svilupparle in una tal certa direzione, sia per bloccarle, oppure per stabilizzarle e utilizzarle" [Foucault 200I, pp. 299, 300].

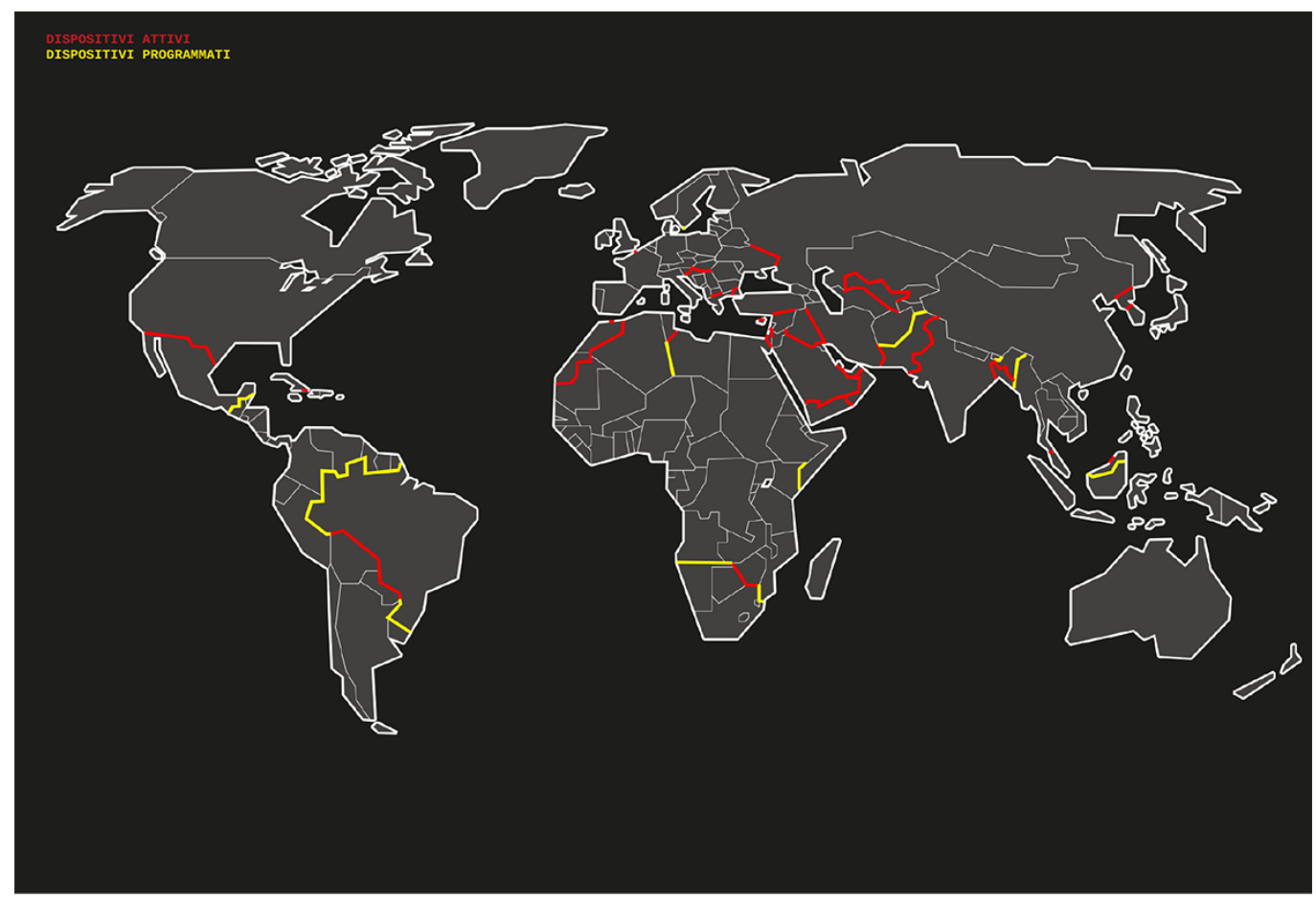

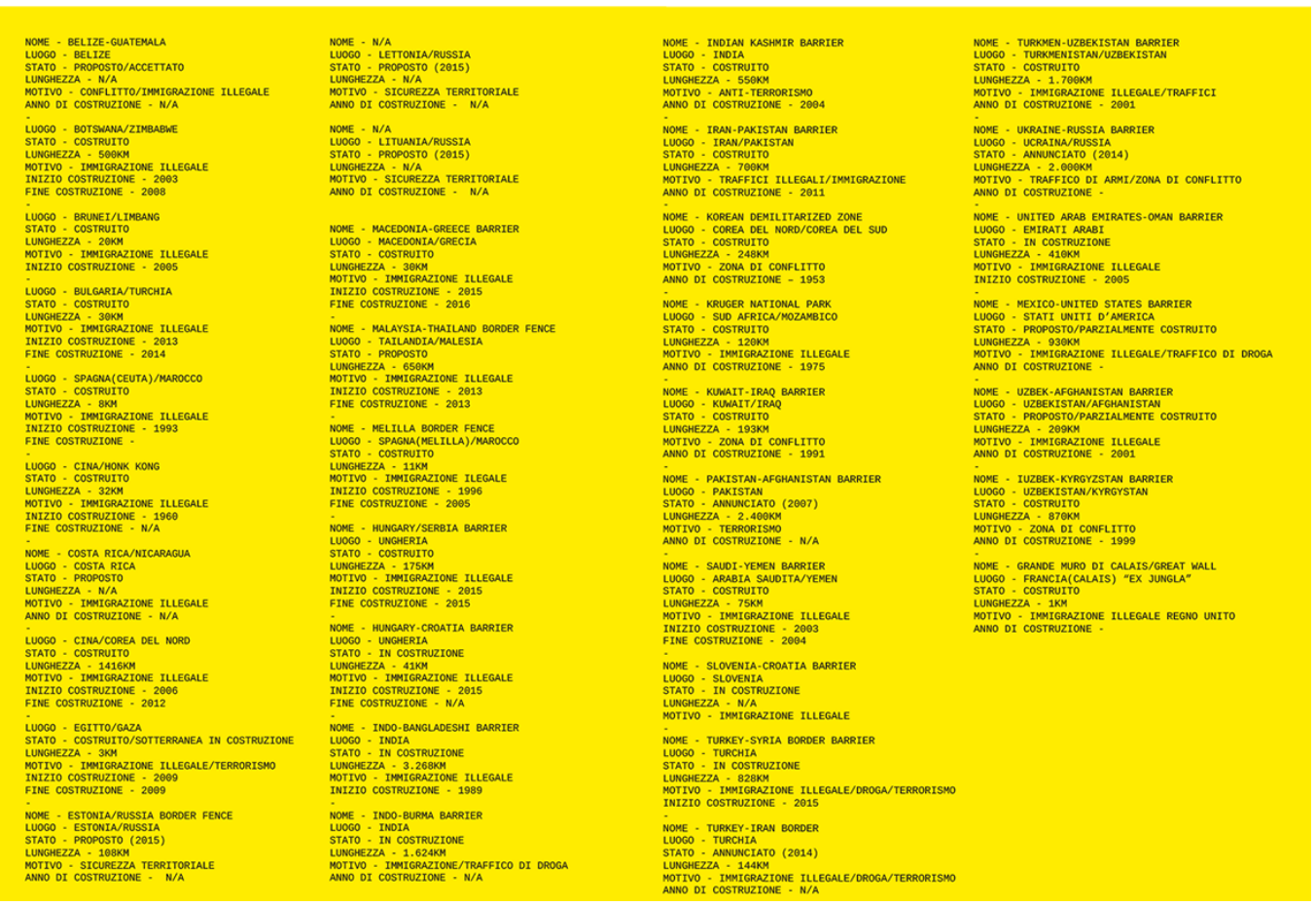


II censimento dei confini controllati da dispositivi più o meno attivi era ampio. L'elenco di quei confini realizzati o anche solo programmati era sorprendentemente lungo, la rappresentazione icastica della loro precisa collocazione sul globo, inquietante (fig. 3) Non si trattava più di ragionare su un muro, ma di intendere i dispositivi di separazione come categoria ineludibile della nostra contemporaneità. II movimento di opinione intorno al progetto di Trump era intenso da anni. Si pensi al prezioso lavoro Leaving on the Edge (fig. 4) con cui Estudio Teddy Cruz+Fonna Forman denunciava e intensamente combatteva sin dai primi anni 2000 contro l'idea dominante nel discorso politico, per cui il confine tra Stati Uniti e Messico è un luogo di criminalizzazione trasformandolo in luogo di creatività diffusa, attraverso azioni progettuali ad alta potenzialità emotiva tutte giocate sul filo della provocazione mediatica e della forza metaforica delle immagini [2].

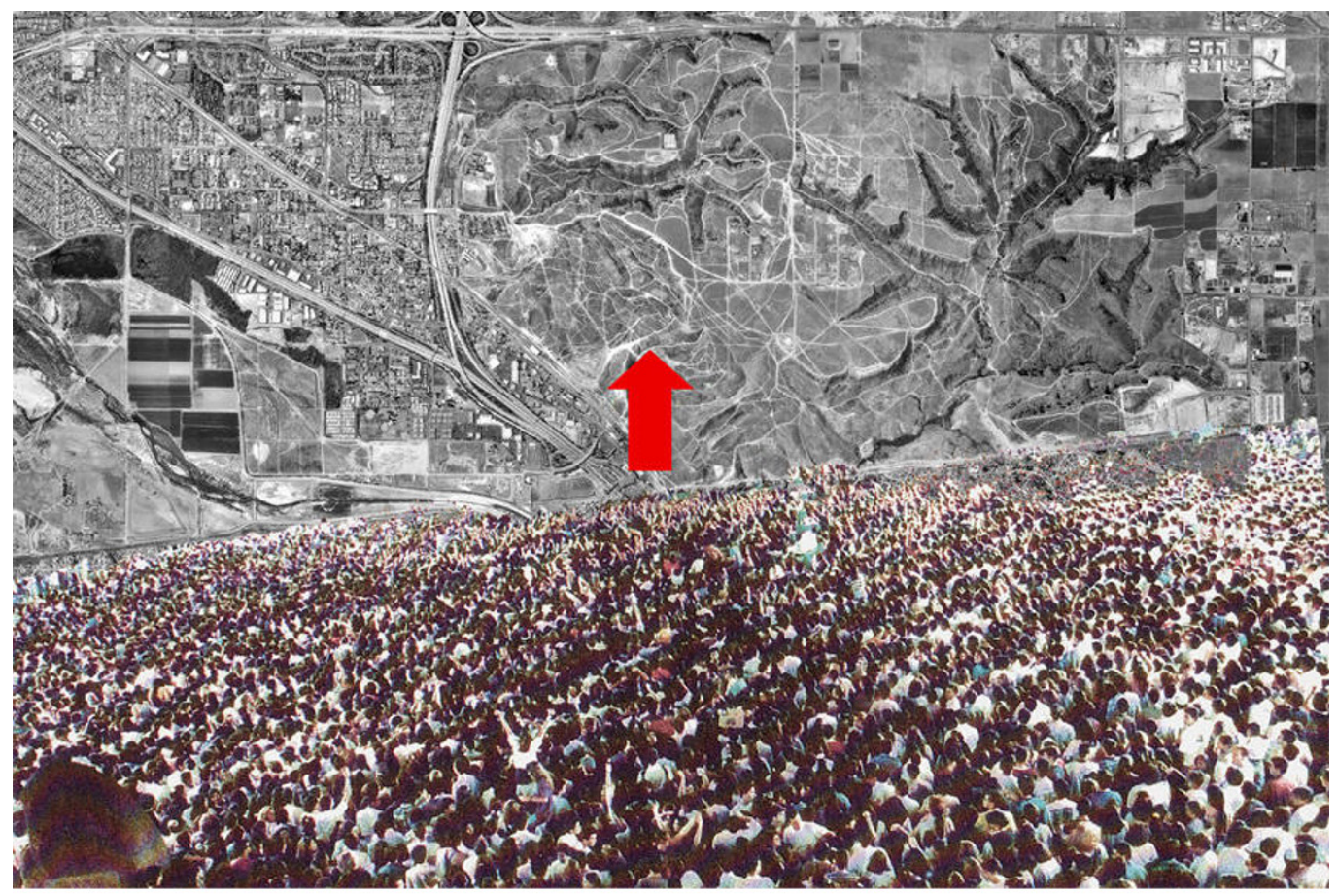

Fig. 4. Estudio Teddy Cruz + Fonna Forman, Border fence. Living at the border MOMA Small Scale, Big Change: New Architectures of Social Engagement San Diego-Tijuana border illustration 2001.

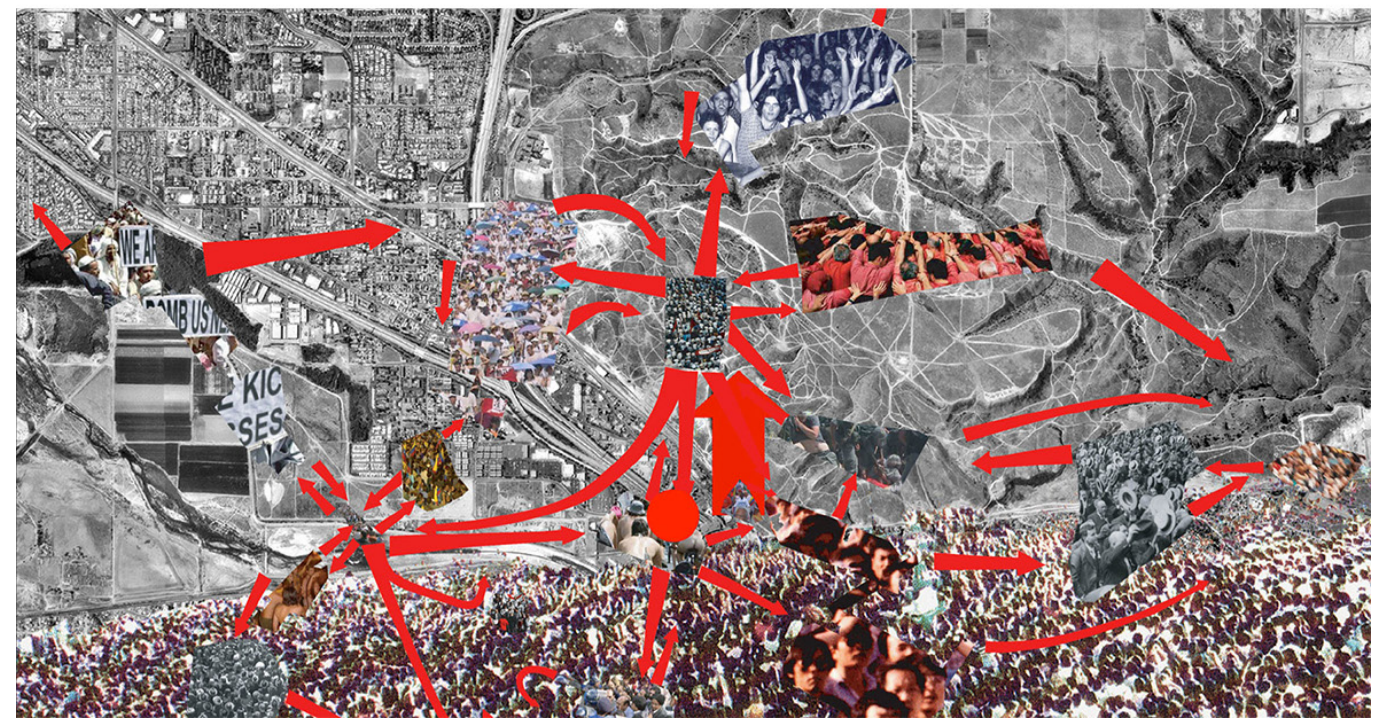


Un lavoro potente di rappresentazione che trova la sua espressione più forte nel 2008 alla II ${ }^{\circ}$ Biennale di Architettura di Venezia, con la bellissima istallazione Border Fence. Una provocatoria riproduzione fotografica a grandezza naturale della recinzione di confine tra USA e Mexico occultava il Padiglione Stati Uniti di America ai Giardini e costringeva, con una forte connotazione metaforica, chiunque volesse accedere al padiglione stesso all'atto fisico dell'attraversamento, infrangendone la superficie e sconfiggendone il senso di limite invalicabile (fig. 5).

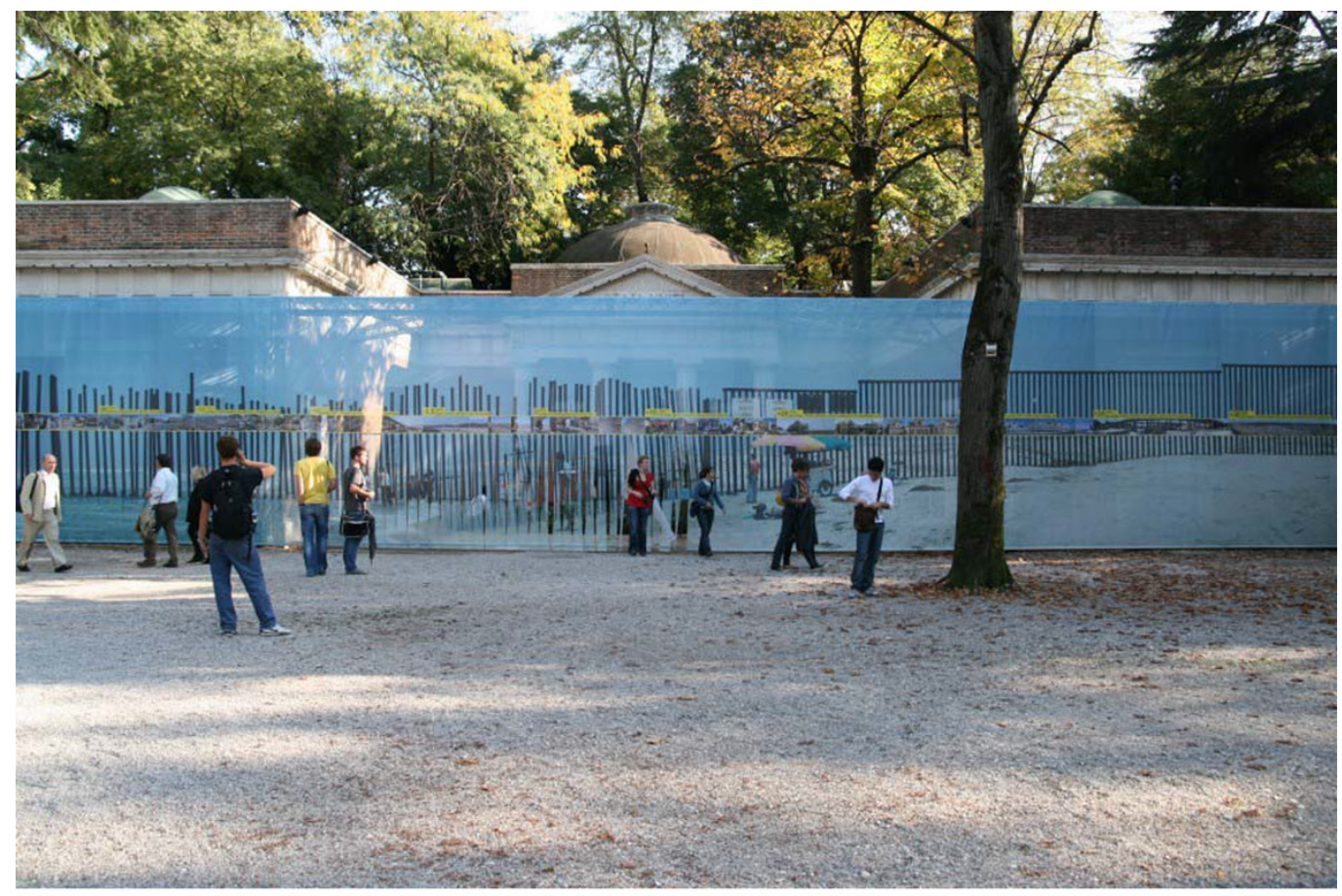

Fig. 5. Estudio Teddy Cruz+Forman, Border fence. Living at the border-, 1 I Biennale diVenezia, Padiglione Stati Uniti d'America 2008 Riproduzione fotografica de confine USA Mexico (foto di Lisbet Arboe).

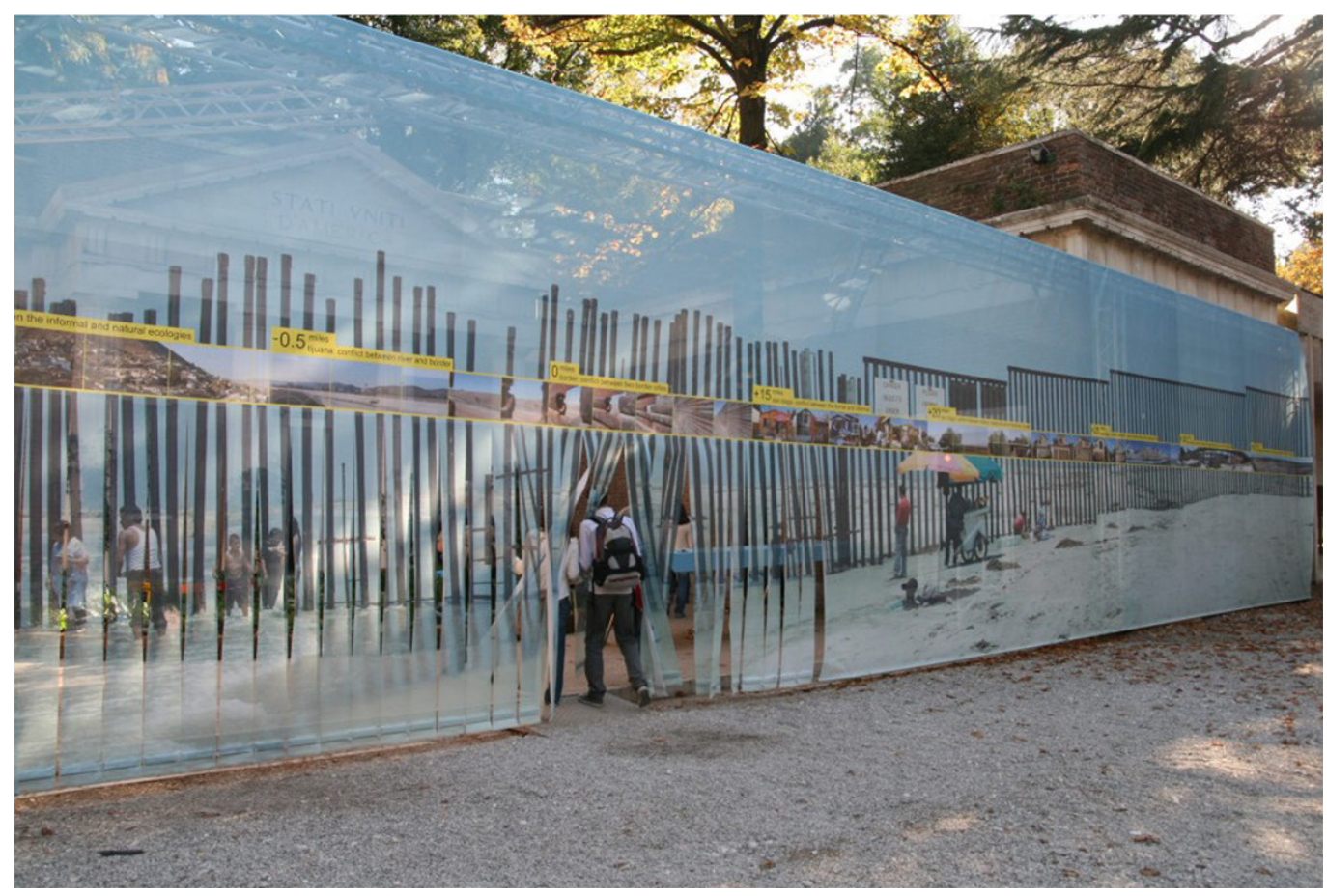


Nella potenza delle immagini realizzate da Teddy Cruz nell'uso diffuso del collage e nella precisa volontà di utilizzare la forza eversiva della rappresentazione, intesa come provocazione, c'è l'eco distinta di una stagione intensa dell'architettura disegnata, ed in modo particolare risuona quello che dal punto di vista concettuale, ha rappresentato il progetto ispiratore dell'approccio che Carmine volle dare al suo American Transracial Agency. Architettura di conflitto. Effetti collaterali. Mi riferisco allo straordinario progetto con cui nel 1972 Rem Koolhaas esordi sulla scena mondiale: Exodus or the voluntary prisoners of architecture [3] (figg. 6, 7). Qui, come spesso accade nell'opera di Koolhaas, il progetto è inteso come una storia da raccontare, come il risultato di una programmazione, come scenario possibile, assai più che come oggetto architettonico in sé. Con un chiaro riferimento alla Berlino della guerra fredda, il progetto, prevede la realizzazione di una struttura di città ideale posta nel cuore di Londra. La suggestione proposta era quella di realizzare un vuoto all'interno della città, racchiuso entro una delle strutture archetipiche dell'architettura: il muro che lo stesso Koolhaas definisce 'magnifico' nella sua relazione al progetto. Un'idea di muro in cui l'elemento viene interpretato, non come semplice struttura portante ma, come simbolo che è in grado di esprimere al massimo livello il significato di separazione. II vuoto tra i due muri viene invece trasformato in una nuova città ideale che riutilizza l'elemento del muro per il suo carattere simbolico e psicologico. II muro viene così trasformato in una forza positiva capace non solo di sovrapporsi alla struttura urbana preesistente, ma anche di imporre un nuovo modello di metropoli in grado di generare a sua volta un nuovo stile di vita segnato da momenti di ritiro quasi mistico e di partecipazione ad attività sociali. Sicché, nella metafora del progetto e della sua narrazione, gli abitanti finiscono via via per scegliere di lasciare la città per trasferirsi in quella 'striscia' diventando così 'prigionieri volontari dell'architettura'. L'idea portante di Exodus è, dunque, quella di utilizzare in chiave positiva la 'forza intensa e distruttiva' dell'architettura rappresentata allusivamente da quel muro metaforico; muro che nella sua essenza era ed è sempre 'strumento e fonte di disperazione'.

Fig. 6. Rem Koolhaas and Elia Zenghelis, with Madelon Vriesendorp and Zoe Zenghelis Exodus, or the Voluntary Prisoners of Architecture. Progetto per il concorso La cittò come ambiente significante 1972.

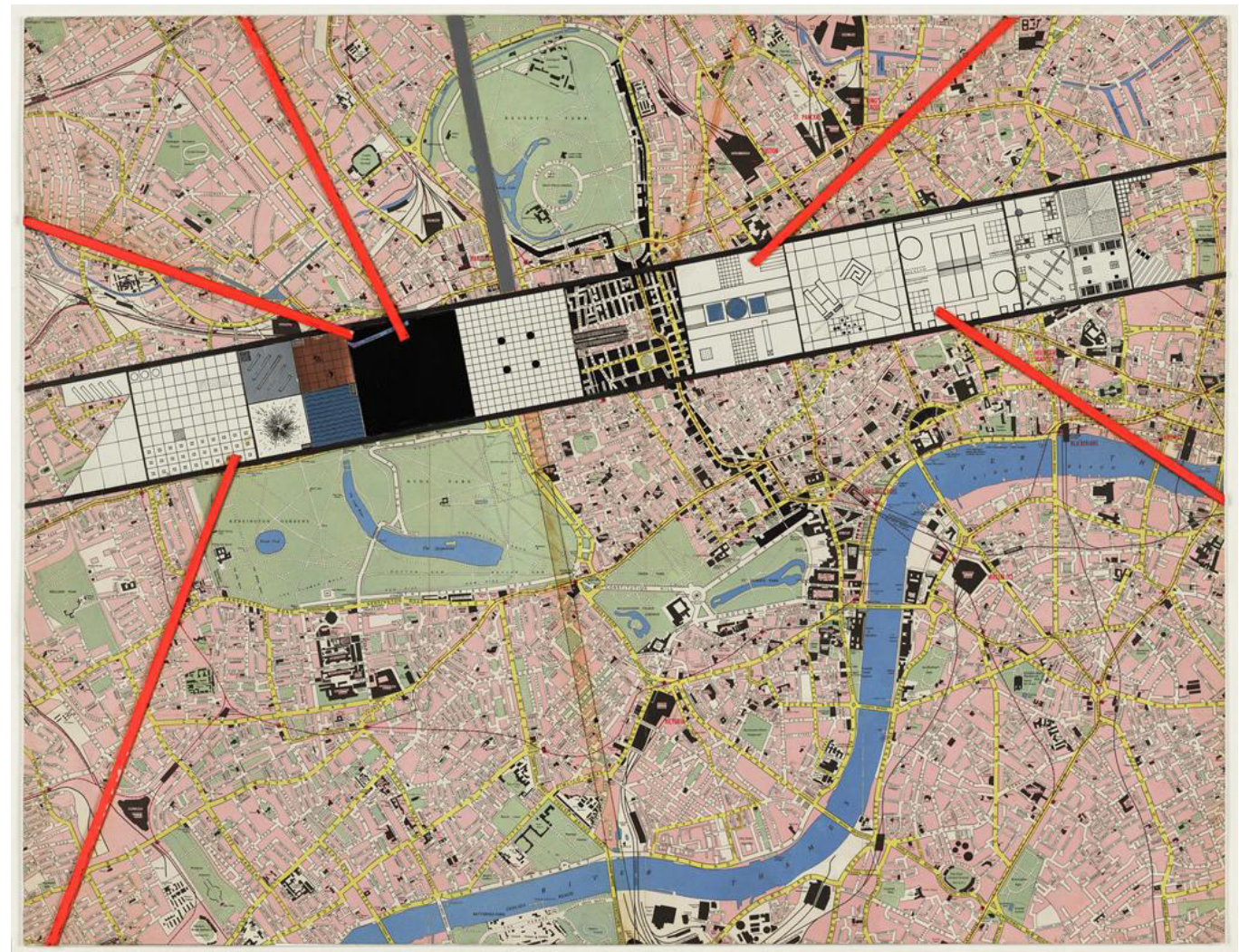



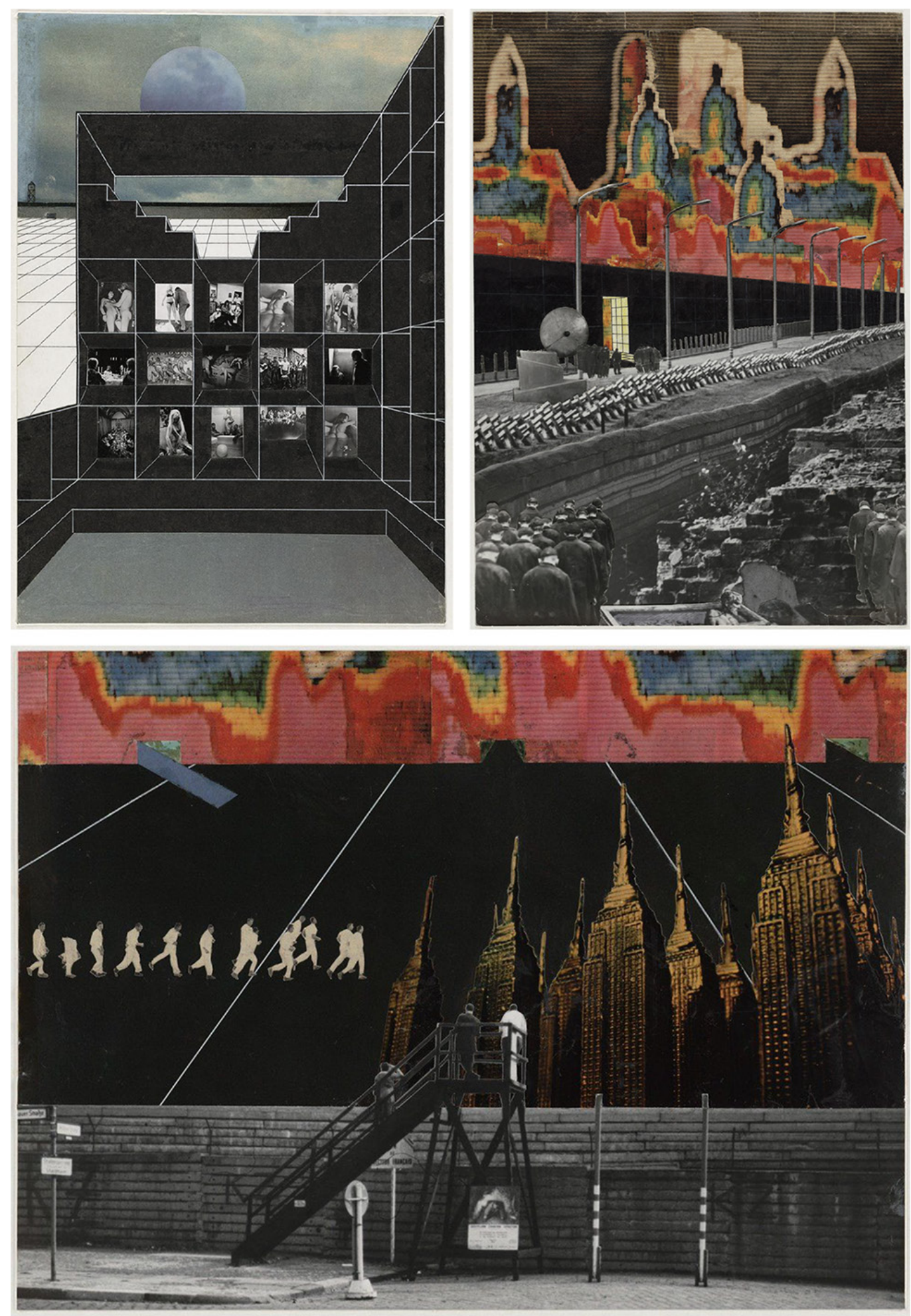
Fig. 8. American Transracial Agency. Architettura di conflitto Effetti collaterali. Tesi di Laurea in ArchiTettura di Carmine Errico a 2016/17 Dipartimento a.2016/17/ Dipartimento Indurtria.

invasione digitale delle informazione relative Agency.

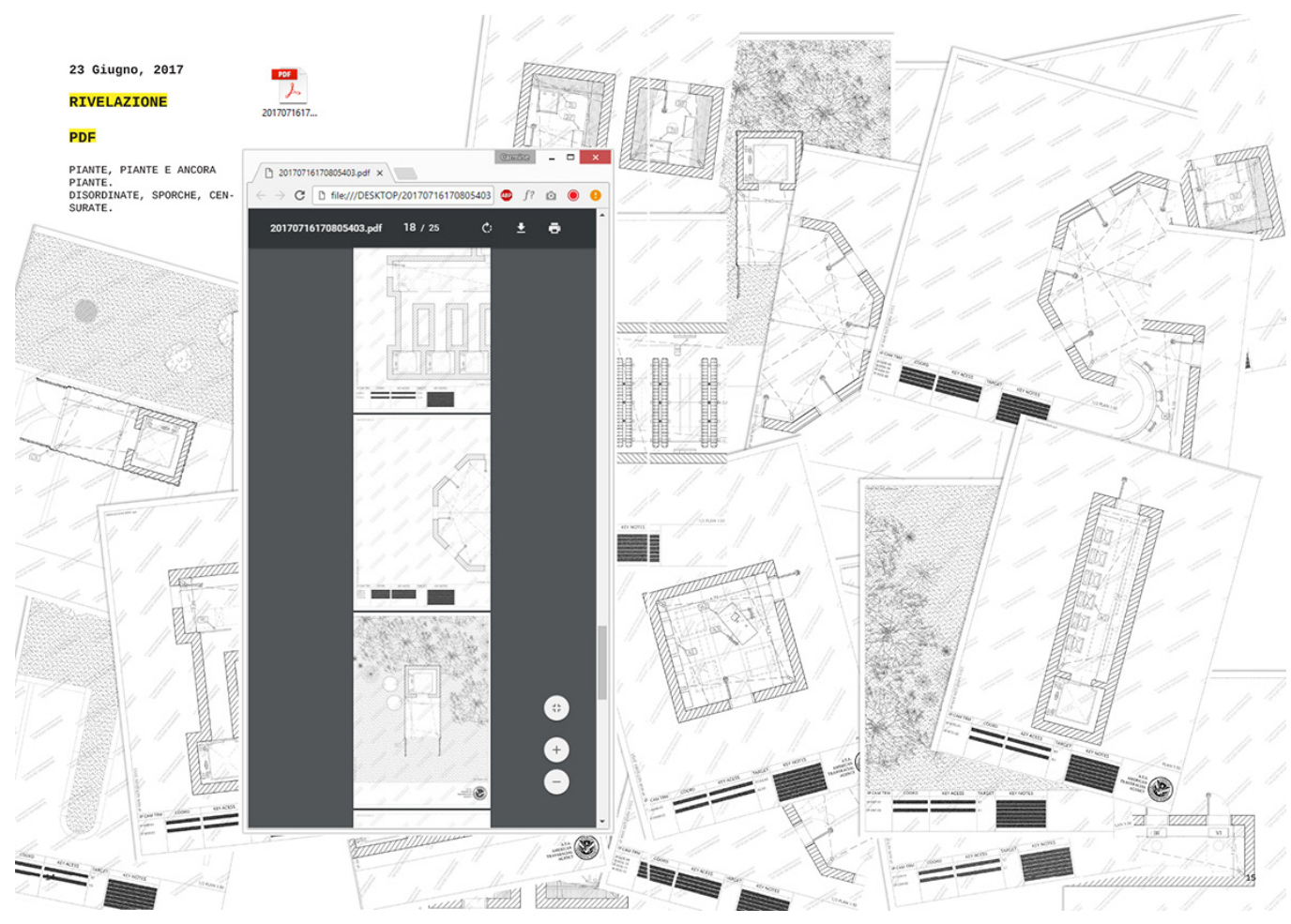

Fig. 9. American Transracia Agency. Architettura di conflitto Effetti collateral. Tesi di Laurea in Archiettura di Carmine Errico a.a.2016/17 Dipartimento di Architettura e Disegno Industriale.

Uno stralcio della se-

quenza spaziale attraver-

so cui avviene il processo di 'mutazione raziale'.

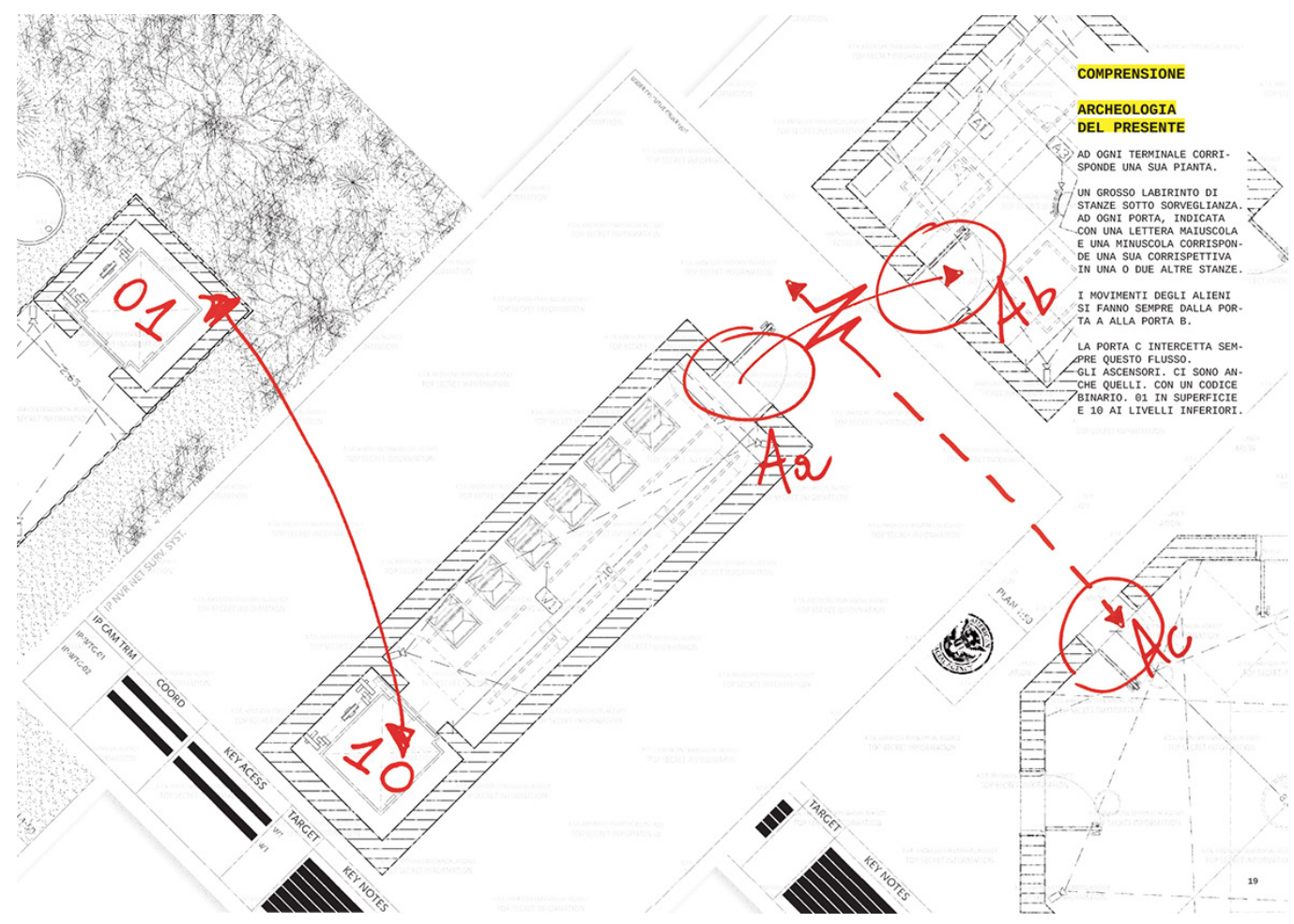




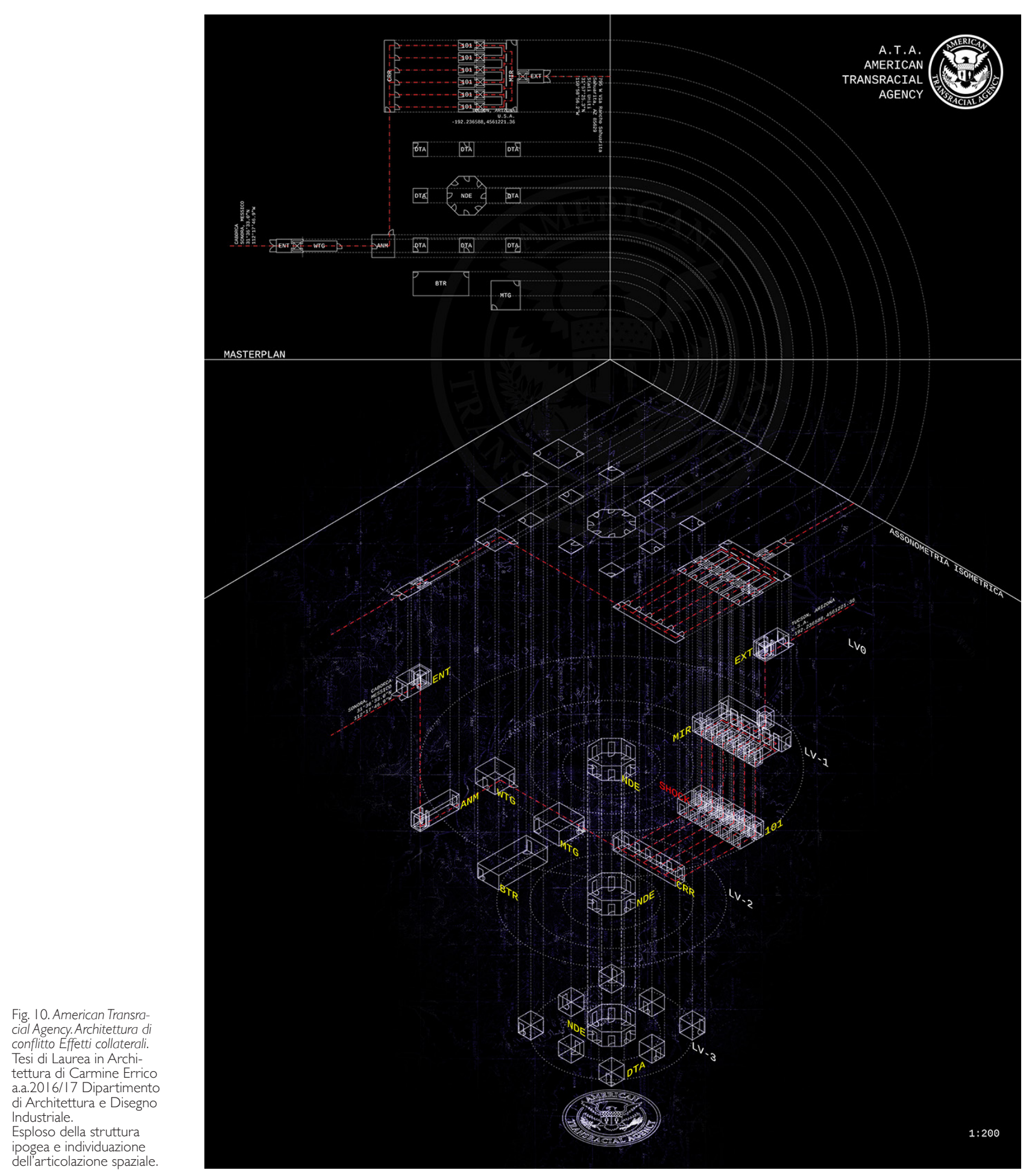


"Ciò che è molto importante è distinguere due tipi di scrittura: una che chiamerei scrittura sulla architettura e una che chiamerei scrittura di architettura. La scrittura sulla architettura è la più comune... i testi sono generalmente descrittivi... ma di per sé non sono architettura... dal 1968 sono stati scritti diversi testi che sono architettura... Sono architetture in sé. In altre parole, propongono forme di strategie architettoniche, letteralmente in forma di sostituto"

[Tschumi 1993, pp.50,5।]

Con analoga attitudine ad intendere la 'rappresentazione' del muro non solo come barriera, ma come reale dispositivo spaziale e dunque 'luogo' in cui accadono cose, il progetto della American Transracial Agency si muove all'interno di una dimensione totalmente immaginaria e surreale proponendo di realizzare uno 'spazio' inteso come un 'processo' innanzitutto concettuale e poi fisico. Uno spazio costituito da dispositivi relazionali che nello 'spessore' concettuale del muro sono capaci - attraverso un sottile gioco dell'assurdo - di neutralizzarne l'effetto di separazione ed esclusione che esso genera e sottende. Gli 'effetti collaterali' della presenza del muro sono, infatti, tutti racchiusi nel progetto di una complessa architettura ipogea collocata nei pressi del confine tra USA e Mexico e composta di aree di accesso, spazi di attesa, spazi di controllo, camere con attivatori neuronali, ascensori, percorsi di entrata e aree di uscita al di là del muro. Elementi di un percorso capace di modificare in tempo reale - e su richiesta dell'interessato! - la 'razza' del soggetto in transito e dunque rendere inefficace la barriera posta in essere dal muro. II tutto descritto attraverso un racconto serrato e una descrizione puntuale dei luoghi e delle azioni, generato dalla improvvisa comparsa sul PC del narratore dei documenti dell'archivio '404': una pioggia di documenti, planimetrie, itinerari, mappe concettuali, foto aeree, che per via di un Bug nella rete internet si diffondono in modo virale, svelano il processo in atto e lo rendono palese al mondo (fig. 8).

Quanto più la narrazione si spinge sul limite dell'assurdo e del fantascientifico tanto più la rappresentazione dei luoghi è verosimile e precisa (fig. 9). Quanto più assurda la condizione di conflitto posta in essere dal muro, tanto più efficace e definitiva la soluzione surreale proposta e descritta con la forza della provocazione progettuale che trova risonanza nelle scelte rappresentative in cui la descrizione del progetto assume la potenza evocatrice di una dichiarazione di intenti grazie alla capacità comunicativa dell'immagine e della sua messa in scena nella presentazione visiva del progetto che attraverso la rappresentazione si fa racconto (fig. I0).

$$
\begin{array}{r}
\text { “quasi all'inizio di ogni progetto c'è [...] } \\
\text { una definizione in parole - un testo - un concetto, un'ambizione, } \\
\text { o un tema che viene messo in parole, } \\
\text { e solo nel momento in cui viene messo in parole s } \\
\text { i può cominciare a procedere, } \\
\text { a pensare all'architettura; } \\
\text { le parole scatenano il progetto. } \\
\text { Tutti i nostri progetti, o i nostri migliori progetti, } \\
\text { sono prima definiti in termini letterari, } \\
\text { che poi suggeriscono un intero programma architettonico [...] } \\
\text { l'architettura è una disciplina intellettuale, } \\
\text { la scrittura è la comunicazione privilegiata } \\
\text { delle nostre discipline intellettuali" } \\
\text { [Koolhaas 1993, pp. 42,43] }
\end{array}
$$

\section{Note}

[I] La tesi di laurea in Architettura con il titolo AMERICAN TRANSRACIAL AGENCY. Architettura di conflitto. Effetti collaterali è stata discussa da Carmine Errico, con lode e dignità di stampa a luglio 2017 presso il Dipartimento di Architettura e Disegno Industriale dell'Università della Campania Luigi Vanvitelli (relatore prof. A. Cirafici, correlatore prof. F. Ippolito). 
[2] Teddy Cruz, architetto urbanista e docente in Public Culture and Urbanism presso il Visual Arts Department della University of California, San Diego, è noto a livello internazionale per le sue ricerche urbanistiche e architettoniche sul confine tra Tijuana e San Diego. Area in cui il suo lavoro è teso ad interpretare i quartieri degli immigrati di confine come luoghi di produzione culturale, da cui ripensare la politica urbana, gli alloggi a prezzi accessibili e le infrastrutture civiche. La sua indagine su questa 'geografia del conflitto' ha ispirato una pratica progettuale ed e una pedagogia della produzione progettuale ricche di suggestioni. Sul suo lavoro e su quello dello Estudio Teddy Cruz + Forman si veda tra gli altri, T. Misra, The Border Is a Way of Reinforcing Antagonism That Doesn't Exist Architect Teddy Cruz and political scientist Fonna Forman want to turn the line between the U.S. and Mexico into a site for creative problem solving'. CityLab: <http://www.citylab.com/housing/20 I7/0I/theurban-laboratory-on-the-san-diego-tijuana-border-teddy-cruz-fonna-forman/5 | 2222/>.

[3] Rem Koolhaas and Elia Zenghelis, with Madelon Vriesendorp, and Zoe Zenghelis, Exodus, or the Voluntary Prisoners of Architecture: Exhausted Fugitives Led to Reception, 1972

\section{Riferimenti bibliografici}

Davidson Cynthia (1993). Rem Koolhaas:Why I wrote Delirious New York. In ANy 0 | Writing in Architecture, may-june, pp.42, 43.

Foucault Michel (200I). Le jeu de Michel Foucault. Da un'intervista apparsa nel 1977 sotto il titolo Le jeu de Michel Foucault, ristampata in M. Foucault, Dits et Ecrits 1954- 1988, tomo III (1976-1979) Parigi, Gallimard, 2004, testo n 206 (2001) pp. 299 300. Davidson Cynthia (1993). Bernard Tchumi: Modes of Inscription. In ANy O | Writing in Architecture, may-june, pp. 50, 5 I.

Davidson Cynthia (1993). Rem Koolhaas:Why I wrote Delirious New York. In ANy O | Writing in Architecture, may-june, pp.42, 43.

Koolhaas Rem (1978). Dalì and Le Corbusier:The Paranoid-Critical Method. In Architectural Design, nr. 48, pp. I52-I64.

Koolhaas Rem (1978). Delirious New York. Oxford: Oxford University Press.

Koolhaas Rem, Zenghelis Elia (1972). Exodus. In Casabella, 378, pp. $42-45$.

Lambert Leopold (20I2). Weaponized Architecture: The Impossibility of Innocence. New York: dpr. Barcelona.

Autore

Alessandra Cirafici, Università degli Studi della Campania "Luigi Vanvitelli", alessandra.cirafici@unicampania.it

Per citare questo capitolo: Cirafici Alessandra (2020). Muri/effetti collaterali/Walls Side effects. In Arena A., Arena M., Brandolino R.G., Colistra D. Ginex G. Mediati D. Nucifora S. Raffa P. (a cura di). Connettere. Un disegno per annodare e tessere. Atti del $42^{\circ}$ Convegno Internazionale dei Docent delle Discipline della Rappresentazione/Connecting. Drawing for weaving relationships. Proceedings of the 42th International Conference of Representation Disciplines Teachers. Milano: FrancoAngeli, pp. $3105-3128$. 


\title{
Walls/Side Effects
}

\author{
Alessandra Cirafici
}

Abstract

Starting from the consideration that stronger the need to 'connect' is, the more pervasive the tendency to 'separate' and build barriers is, this paper will try to propose some considerations on the power of representation and its ability to build real or ideal bridges between ideas, words and things, going beyond as the call suggests "with the force of provocation, simple rational thought". In particular, the theme of physical or virtual barriers, intended as places of conflict between peoples and cultures, will find its exemplary case in the wall loudly evoked by the Trump administration on the US-Mexico border. Metaphor par excellence of the theme evoked, we will try to describe its contours starting from the media narrative, up to the proposal of a project-manifesto that, responding to the announcement issued by the USA, defeats the assumptions using representation, in its meaning of accelerator of design thinking, in a process of critical interpretation of reality that holds together space and society.

Keywords

wall, conflict, militant architecture, representation, narrative.

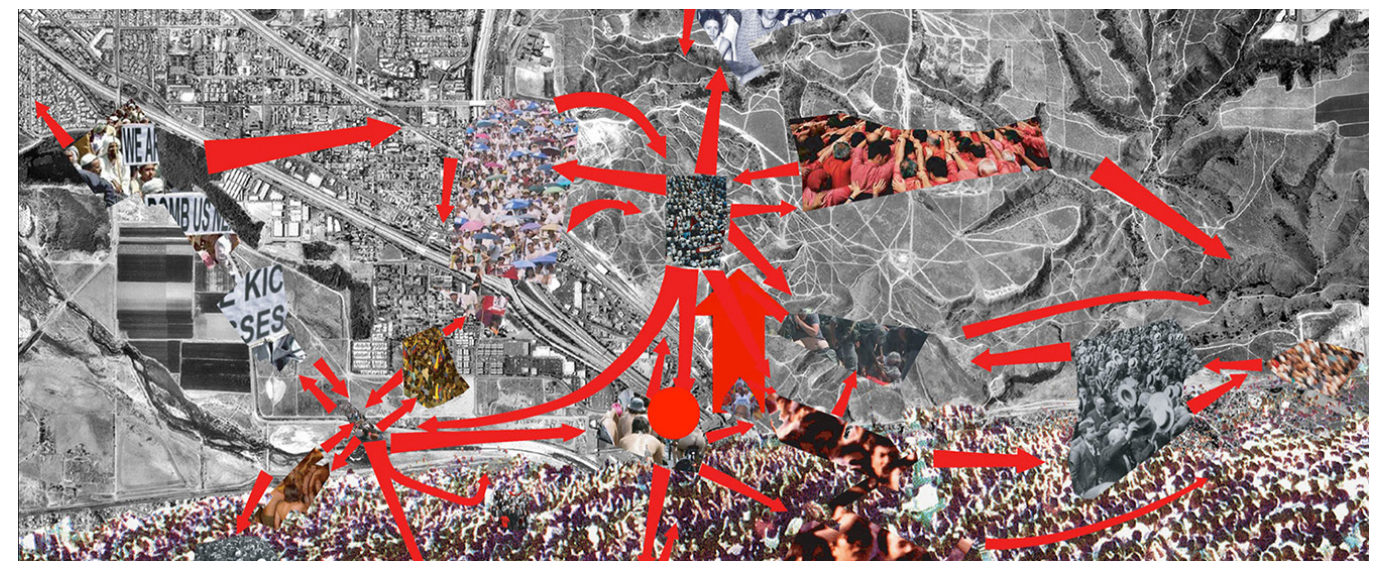




\begin{abstract}
"What does it mean that architecture is a political weapon? To answer this question, we need to see how architecture, in the first instance, is a weapon (i.e., how architecture has a propensity for violence) and in the second instance, how this propensity is necessarily exploited by one or several political agendas'
\end{abstract}

[Lambert 2013, p. 59]

The following considerations are developed by testing the tools of representation and design of architecture, as areas of possible critical interpretation of living space. A space in continuous becoming, understood as a space of relations and connections, of interferences and conflicts. In this critical horizon, representation stops interpreting the exclusively descriptive role of the real to assume that of powerful narrator of its complexity and therefore of activator of imagination and critical thinking, working in perfect harmony with the logic of the project of which it turns out to be an integrant part. What is more, representation understood in this way shows itself as a critical instrument of interpretation, of discretization, of an arbitrary but conscious reduction of complexity, in the elements of a visual synthesis that is, in itself, a design act. The result of which is first of all to decode the syntax of the elements of the existing, sometimes to propose a new one that is able to take into account the reasons and tensions of an urban space as a 'living space' in which to design new attributions of meaning. A work of 'unveiling' reality that interprets the truest meaning of 'representation'. In this perspective, the communicative aspect of representation takes over, making it possible to set up real 'manifestos' in which critical thought finds expressive forms and potentially becomes a project. At the same time, as in past eras of mobilization and militancy, the project itself is a manifesto, an exasperation of chosen aspects of reality, brought to extreme consequences in prefigurations of possible, desirable or terrible worlds, present 'in nuce' in the world we live in.

The possibility of using design thinking as a powerful detonator of social denunciation through a refined intellectual work, all played on the border between reality and imagination, focusing on the burning theme of the physical, material and/or immaterial 'boundaries' that dot our world, represented the occasion of the case study that is brought to the attention of our scientific community.

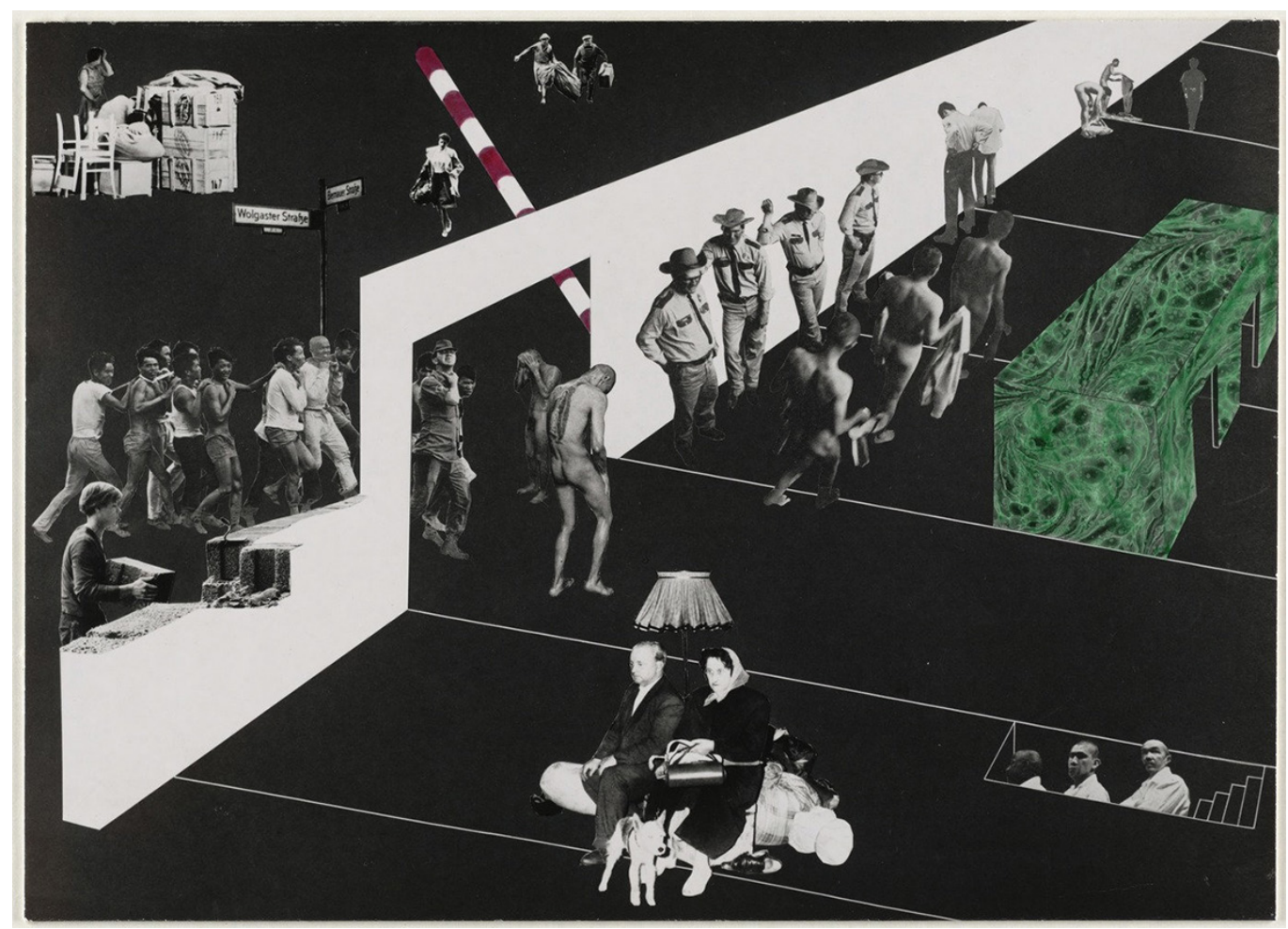

Fig. I. Rem Koolhass, Exodus or the Voluntary Prisoners of Architecture London, UK | 1972 Rem Exhausted Fugitives Led to Reception Exodus, or the Reception Exodus, or of Architecture, 1972 


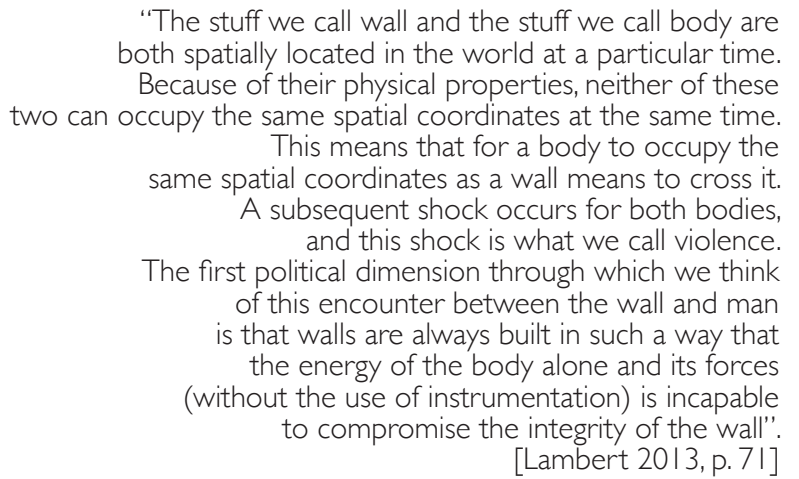

A few years ago, a brilliant and visionary student - one of those in whose intense gaze you sometimes find the meaning and the reasons why you undertook this journey - proposed a theme for his thesis in Architecture to me: he wanted to participate in the "Solicitatio Number 201 7-JC-RT-OO I" with which on February 24, 2017 the Office U.S. Coustoms and Border protection of the Department of Homeland Security requested "Designing and building of several prototype wall structures in the vicinatory of the United States border with Mexico" [I].

In a few words Carmine, that was my student's name, seriously asked me to participate in the Trump administration's electronic request to propose ideas and prototypes for the design and construction of various protective structures near the Mexican border. The contract, conducted in two phases, required presenting, in the first phase, a 'conceptual' document by March 10,2017. A little more time, two weeks, for a project that was supposed to occupy a portion of territory of about 3000 kilometres. It took me a second to understand the extent of the provocation and I accepted the challenge. First of all, I asked Carmine to build a detailed documentation of the route through which the idea of the wall had been formalized in Trump's mind and then it was conveyed to the American public opinion (fig. I).

The result was a document of extraordinary interest in which the representation of the idea of Trump's wall formed the backdrop for a highly articulated narrative on the theme of 'physical control devices' and 'active separation devices' which, far beyond the single episode in question, were present worldwide (fig. 2).

Fig. 2. Chronology of the genesis and communication of the wall proposal between the USA and Mexico from the first statements up to the publication of the call in February 2017.
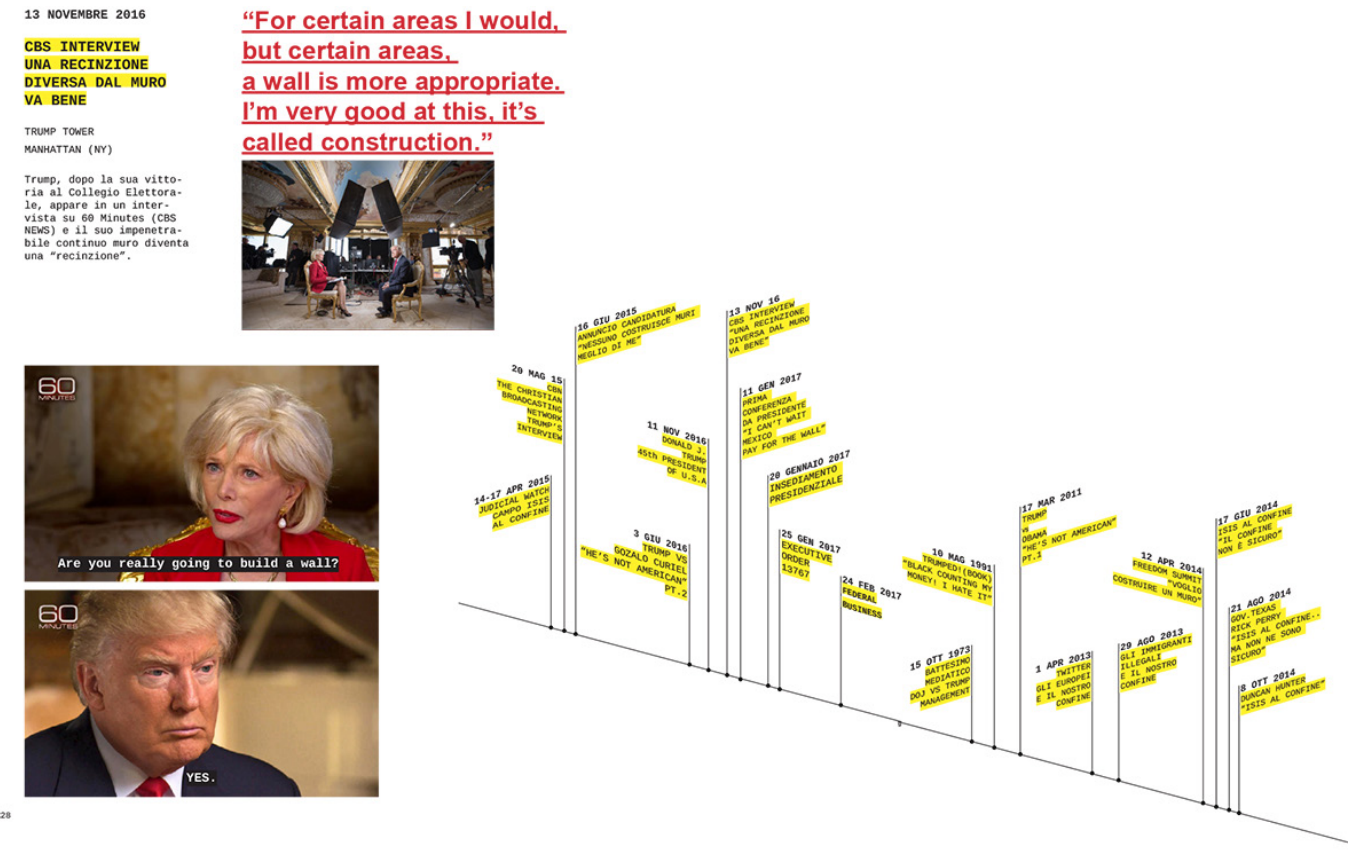
The term 'device' is not chosen at random, but perfectly reflected Michel Foucault's understanding that by 'device' meant "an absolutely heterogeneous whole involving discourse, institutions, architectural structures, regulatory decisions, laws, administrative measures, scientific statements, philosophical, moral and philanthropic propositions", so that, when declined in the specific field of border control, the concept of 'device' ends up being perfectly fitting with an idea of "a "dominant strategic function [...] manipulation of ratios of forces, and rational and concerted intervention in these ratios of forces, either to develop them in such a certain direction, or to block them, or to stabilize them and use them" [Foucault 200I, pp. 299, 300].

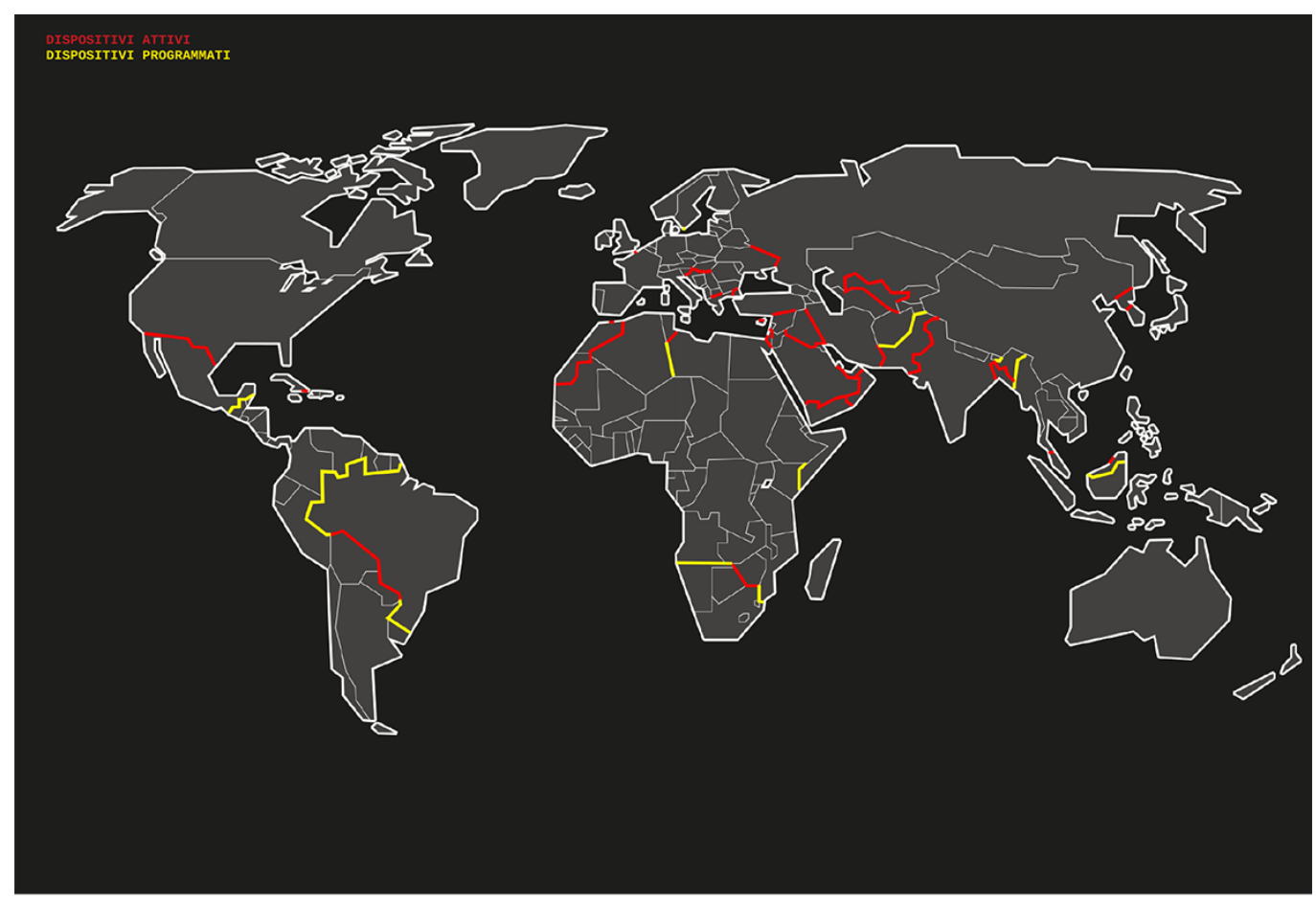

Fig. 3. Survey of active physical control and separation devices, implemented or planned, in the world geopolitical system by 2017 .

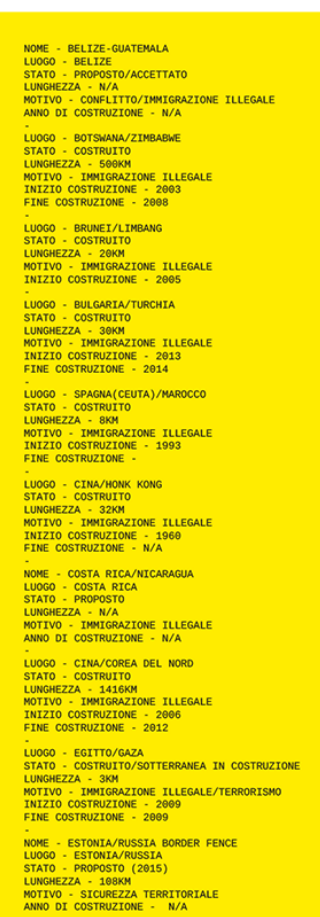

\begin{tabular}{|c|c|}
\hline 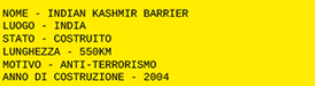 & 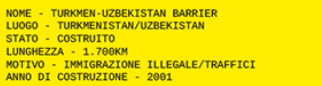 \\
\hline 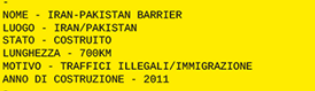 & 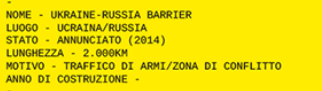 \\
\hline 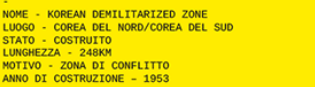 & 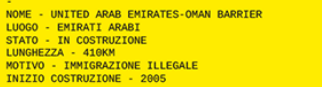 \\
\hline 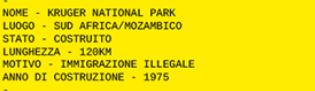 & 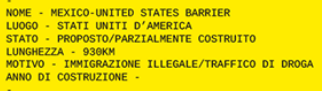 \\
\hline 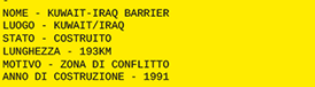 & 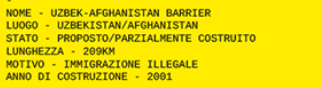 \\
\hline 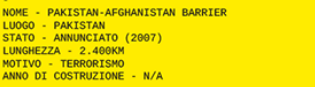 & 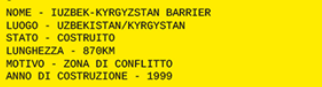 \\
\hline 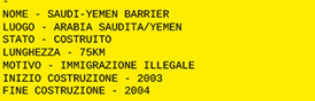 & 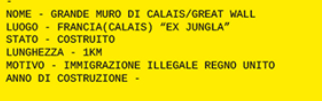 \\
\hline 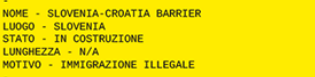 & \\
\hline 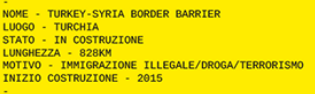 & \\
\hline 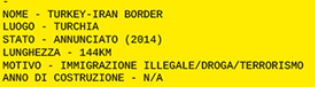 & \\
\hline
\end{tabular}


The mapping of borders controlled by more or less active devices was extensive. The list of those boundaries made or even programmed was surprisingly long, the iconic representation of their precise location on the globe, disturbing (fig. 3). It was no longer a question of reasoning on a wall, but of understanding separation devices as an inescapable category of our contemporaneity. The movement of opinion around Trump's project had been intense for years. Think of the precious work Leaving on the Edge (fig. 4) with which Estudio Teddy Cruz + Fonna Forman denounced and intensely fought since the early 2000s against the dominant idea in political discourse, for which the border between the United States and Mexico is a place of criminalization. With a lot of project activities, they tried to transform it into a place of widespread creativity, through design actions with high emotional potential, all played on the thread of media provocation and metaphorical force of images [2].

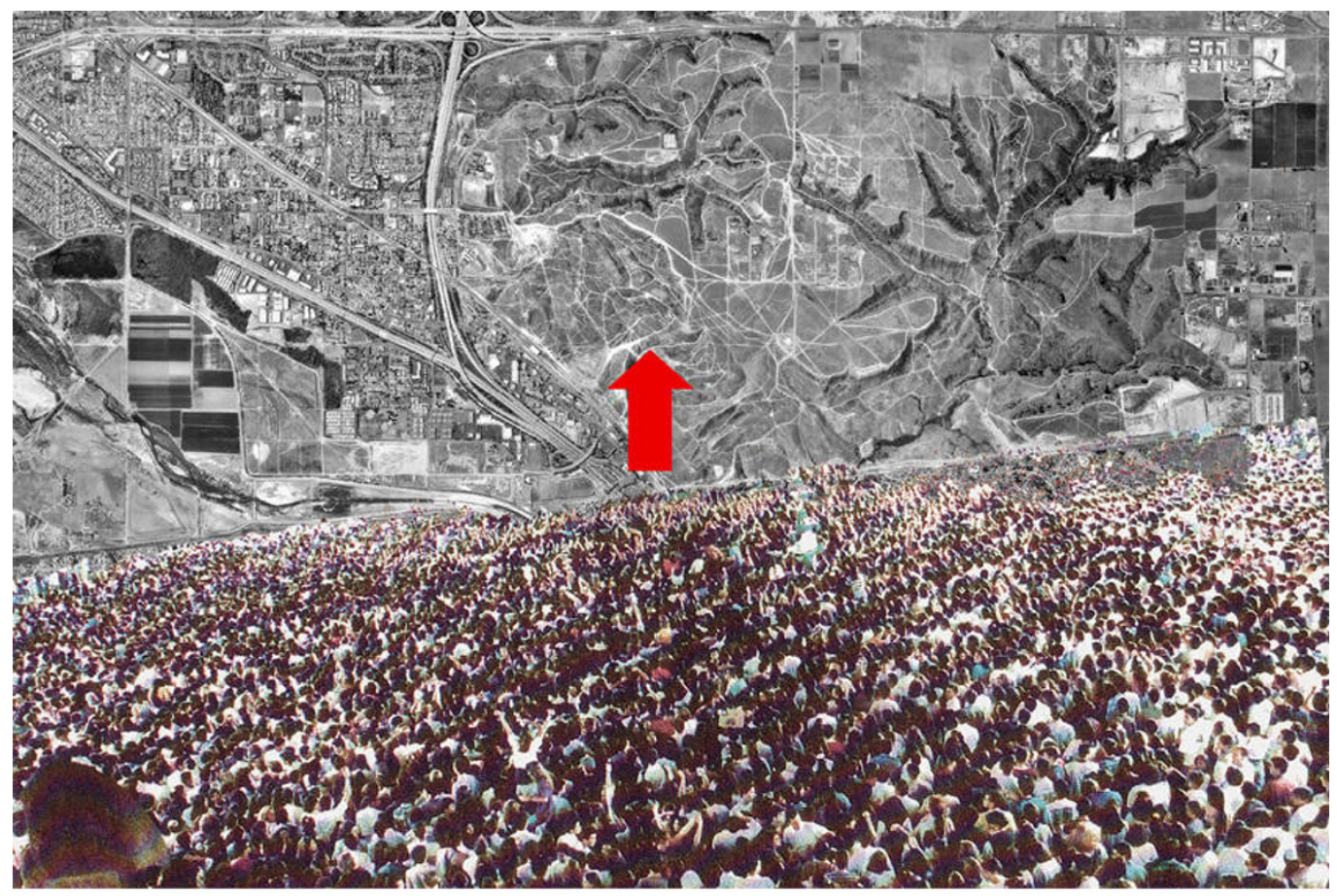

Fig. 4. Estudio Teddy Cruz + Fonna Forman, Border fence. Living at the border MOMA Small Scale, Big Change: New Architectures of Social Engagement San Diego-Tijuana border illustration 2001.

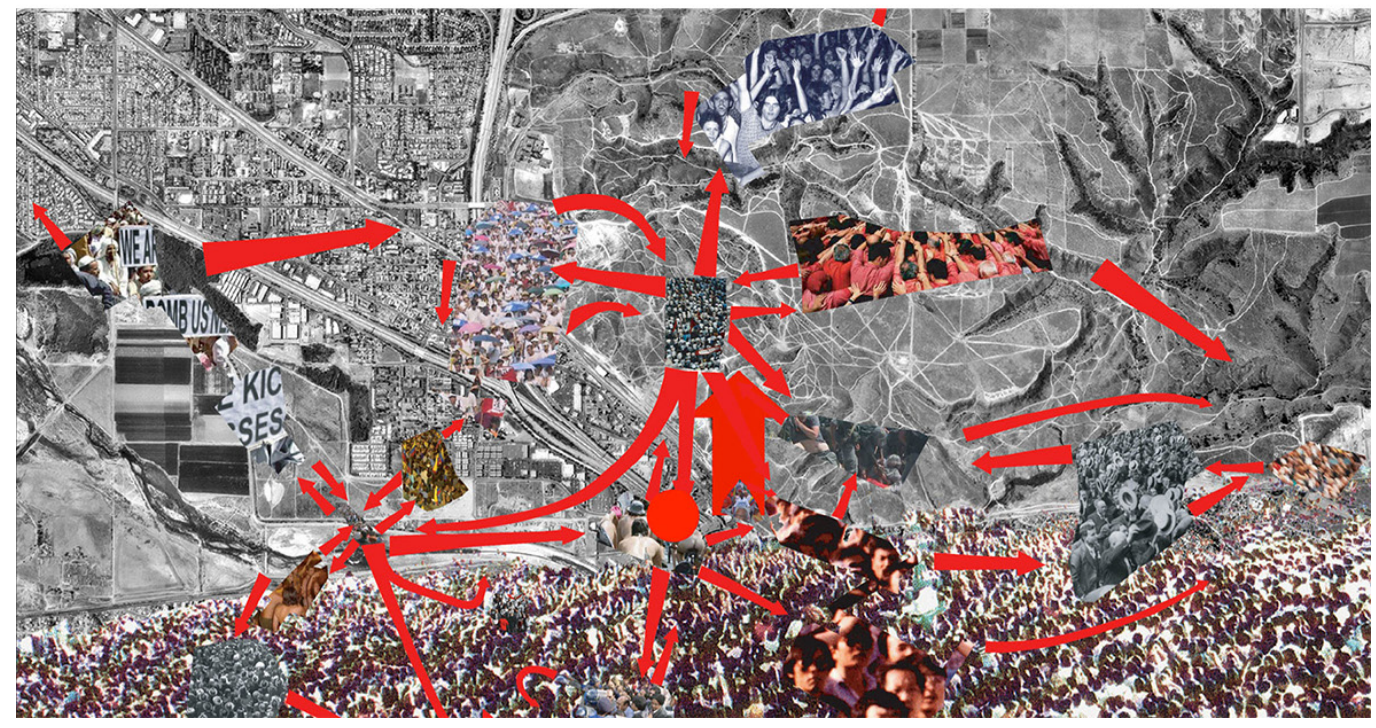


A powerful work of representation that finds its strongest expression in 2008 at the I I th Venice Architecture Biennale, with the beautiful installation Border Fence. A provocative life-size photographic reproduction of the border fence between the USA and Mexico hidden in the United States Pavilion in the Giardini and forced, with a strong metaphorical connotation, anyone who wanted to access the pavilion itself to the physical act of crossing, breaking its surface, and defeating its sense of impassable limit (fig. 5).

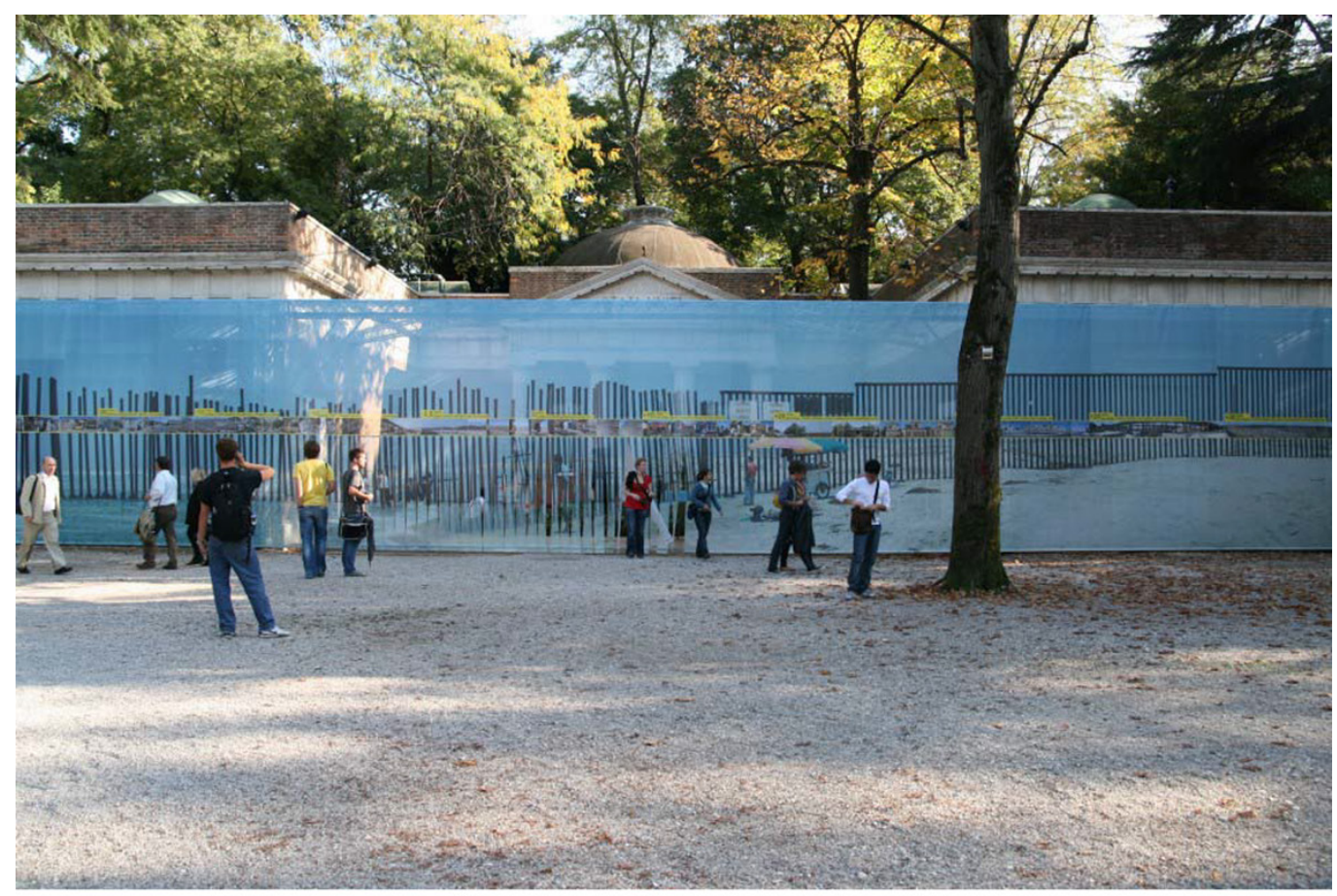

Fig. 5. Estudio Teddy Cruz+Forman, Border fence. Living at the border-, II Venice Biennale, United States Pavilion 2008 Photographic reproduction of the US-Mexico border (photo by Lisbet Arboe).

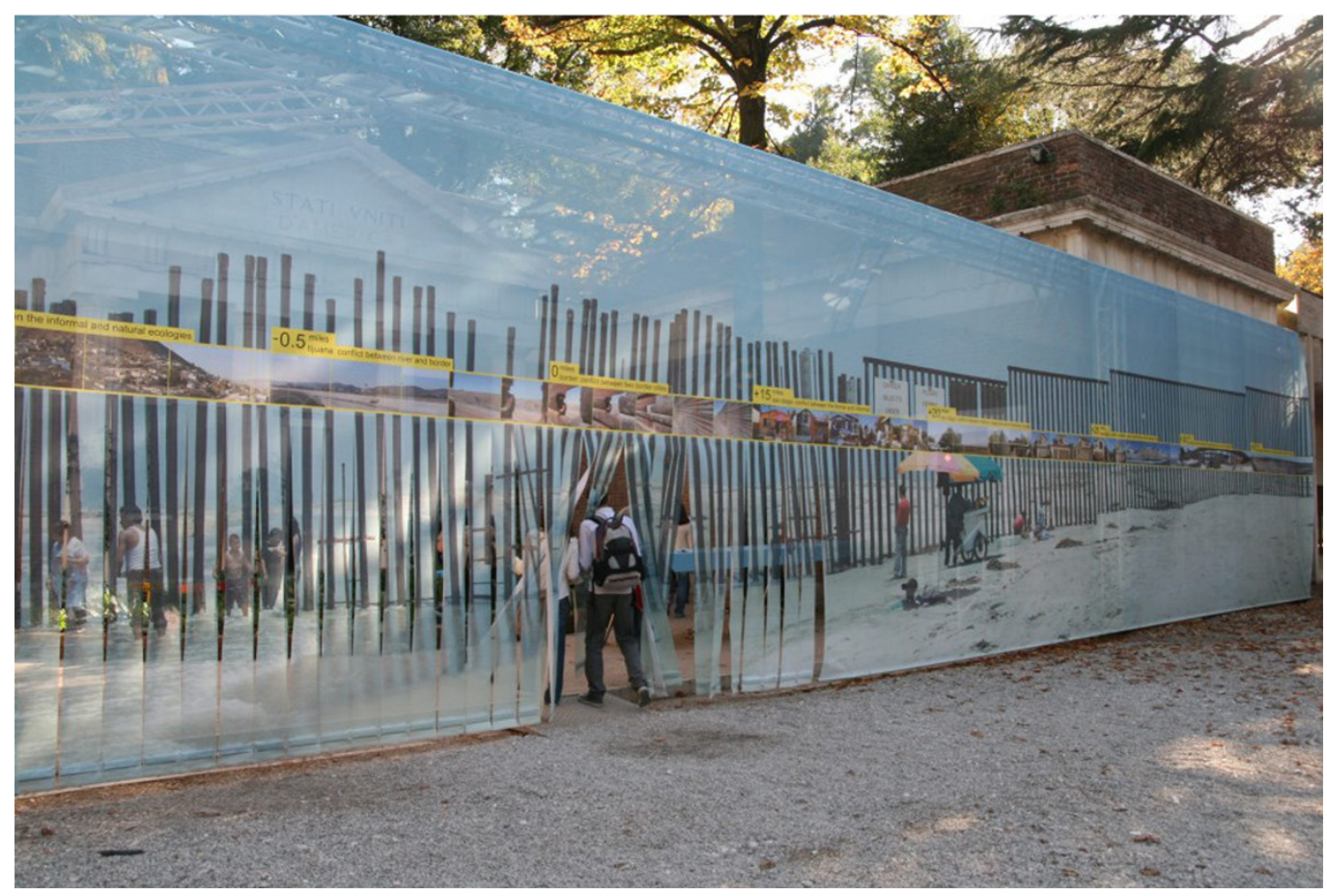


In the power of the images created by Teddy Cruz in the widespread use of collage and the precise desire to use the subversive force of representation, understood as provocation, there is the distinct echo of an intense season of designed architecture, and in a particular way it resounds what, from a conceptual point of view, represented the project that inspired the approach that Carmine wanted to give to his. American Transracial Agency. Architettura di conflitto. Effetti collaterali. I refer to the extraordinary project with which Rem Koolhaas made his world debut in 1972: "Exodus or the voluntary prisoners of architecture" [3] (fig. 7). Here, as often happens in Koolhaas' work, the project is understood as a story to be told, as the result of planning, as a possible scenario, much more than as an architectural object in itself. With a clear reference to the Berlin of the Cold War, the project envisages the creation of an ideal city structure in the heart of London. The proposed suggestion was to create a void within the city, enclosed within a space delimited by one of the archetypal structures of architecture: the wall that Koolhaas himself defines as 'magnificent' in his relationship to the project. An idea of a wall in which the element is interpreted, not as a simple load-bearing structure but as a symbol that is able to express at the highest level the meaning of separation. The void between two walls is transformed into a new ideal city that reuses the idea of the wall for its symbolic and psychological character. The wall is thus transformed into a positive force capable not only of overlapping the pre-existing urban structure, but also of imposing a new model of metropolis, capable of generating a new lifestyle marked by moments of almost mystical retreat and participation in social activities. In the metaphor of the project and its narrative, the inhabitants gradually end up choosing to leave the city and move to that 'strip', thus becoming 'voluntary prisoners of architecture'. The main idea of Exodus is, therefore, to use in a positive way the 'intense and destructive force' of architecture, symbolized by that metaphorical wall, that was and is invariably 'instrument and source of despair'.

Fig. 6. Rem Koolhaas and Elia Zenghelis, with Madelon Vriesendorp and Zoe Zenghelis Exodus, or the Voluntary Prisoners or the Voluntary Prisoners of Architecture. Contest project The city as a signi-
ficant environment 1972 .

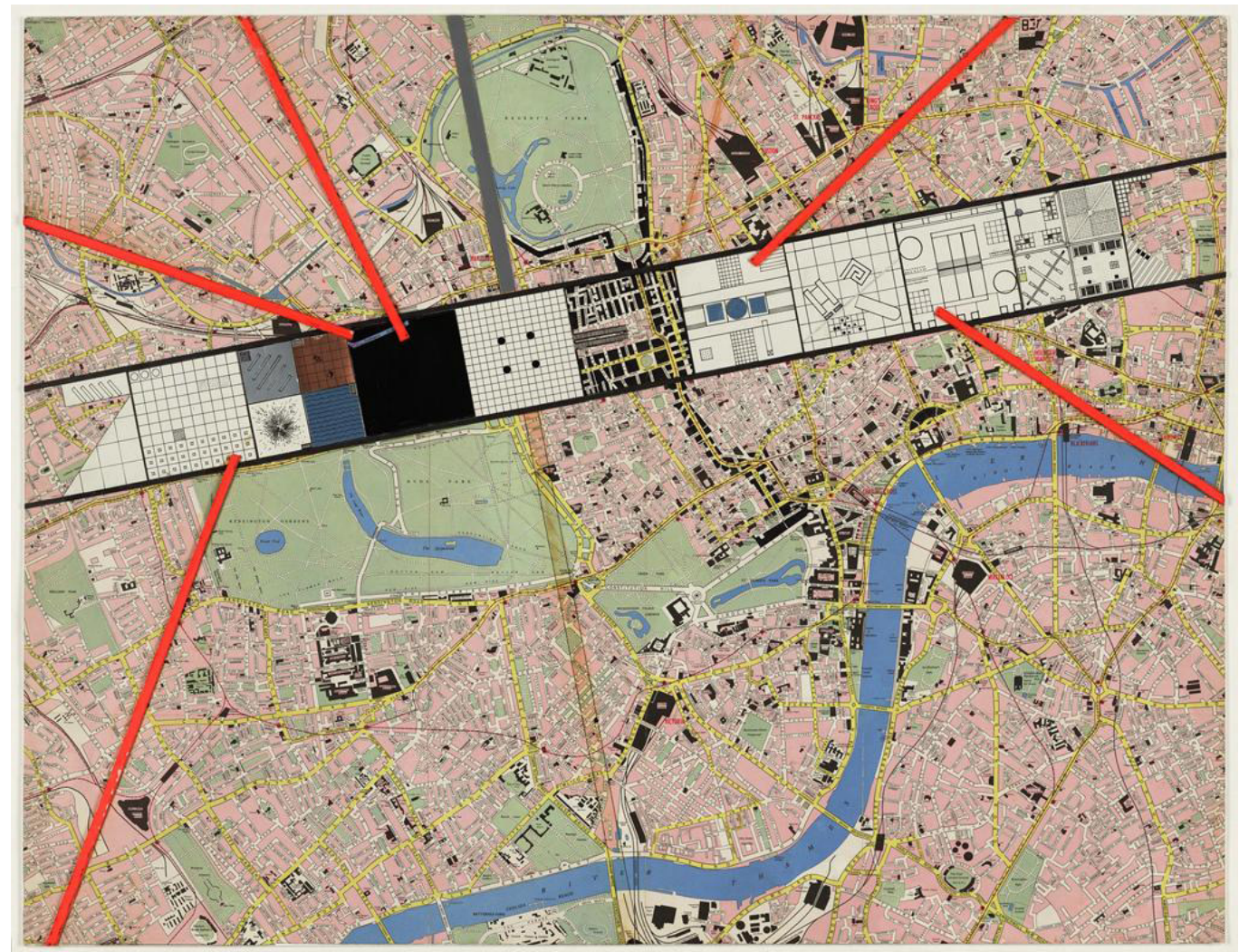



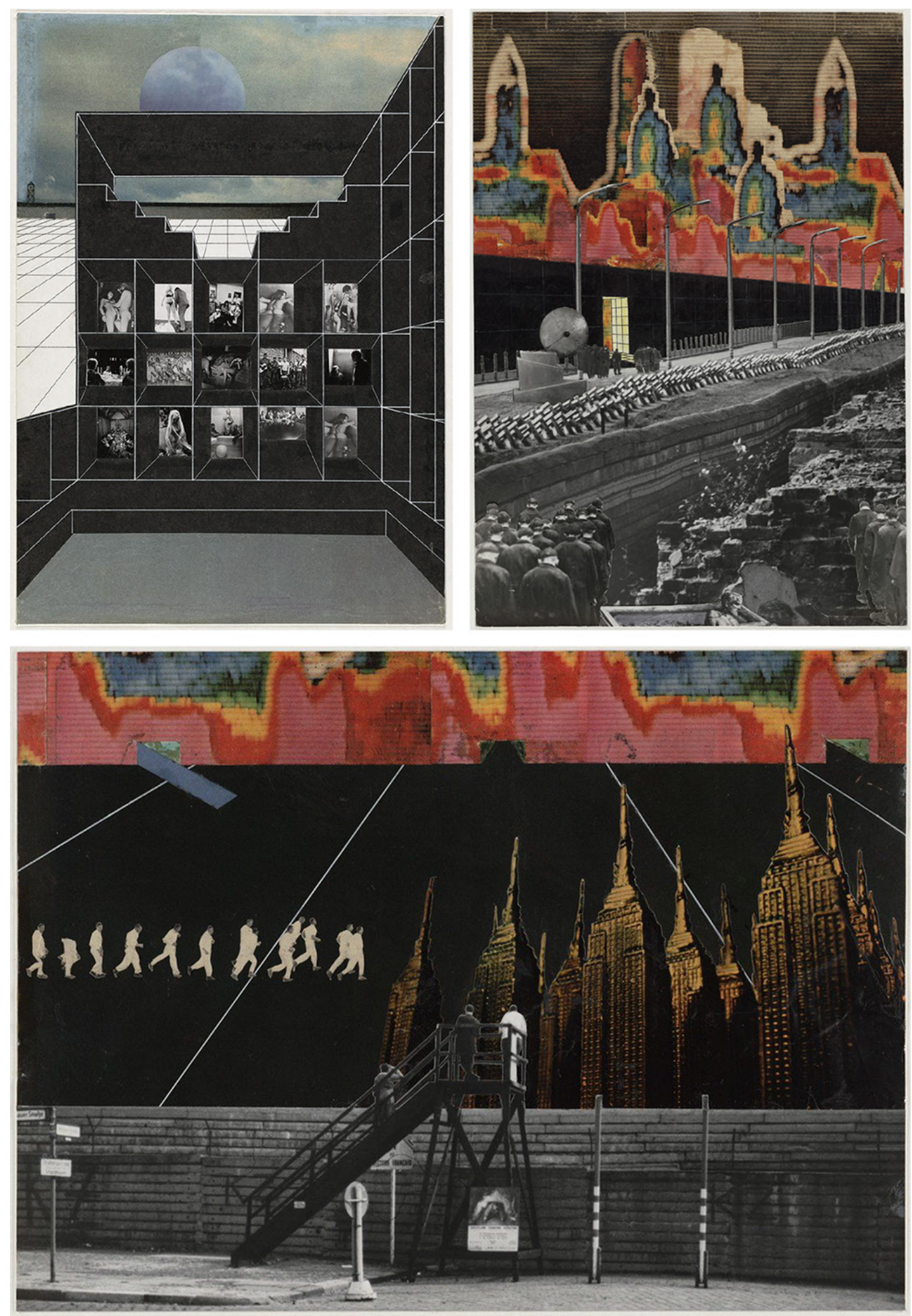

and E. Zenghelis, Exodus, MOMA, watercolors and collages. 
Fig. 8. American Transracia Agency. Architettura conflitto Effetti collaterali, Carmine Errico,

Dissertation in Archi-

tecture, a.y. 2016/17. De-

partment of Architecture

and Industrial Design,

University of Campan,

"LuigiVanvitelli" The digi-

"Luigivanitelli. The digi-

tal invasion of information

related to the American
Transracial Agency.

Fig. 9. American Transracia Agency. Architettura di conflitto Effetti collaterali. Carmine Errico, Dissertation in Architecture, a. 2016/17 Department of Architecture and Industrial Design, University of Campania "Luigi Vanvitelli". An excerpt from the spatial sequence through which the process of

'rational mutation' takes place.
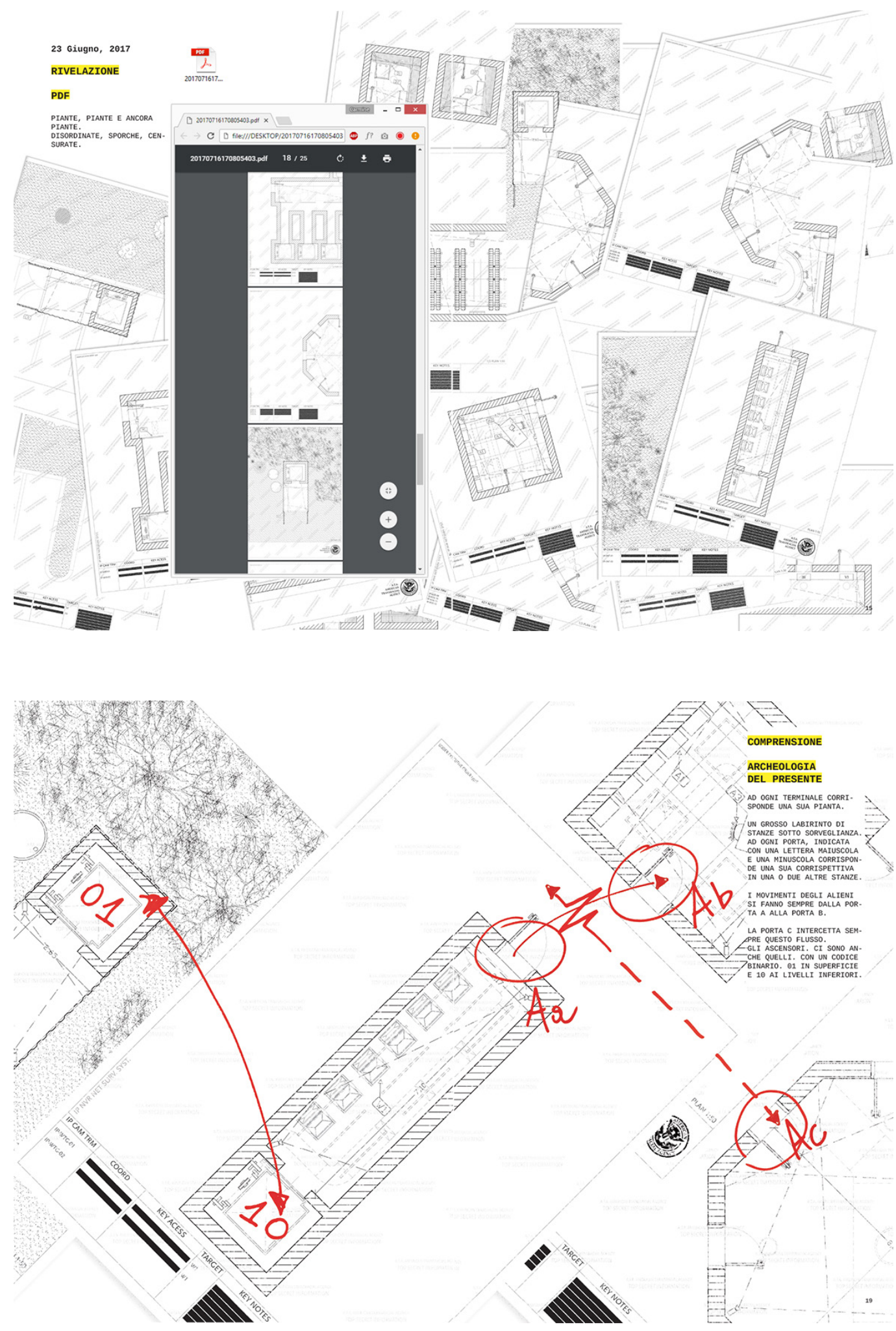
Fig. 10. American Transracial Agency. Architettura di conflitto Effetti collateral Carmine Errico, Disser-

tation in Architecture, a.y 2016/I7 Department of Architecture and

industrial Design, University of Campania "Luigi anvitelli". Isometric view of the hypogeal structure and identification of the spatial articulation.

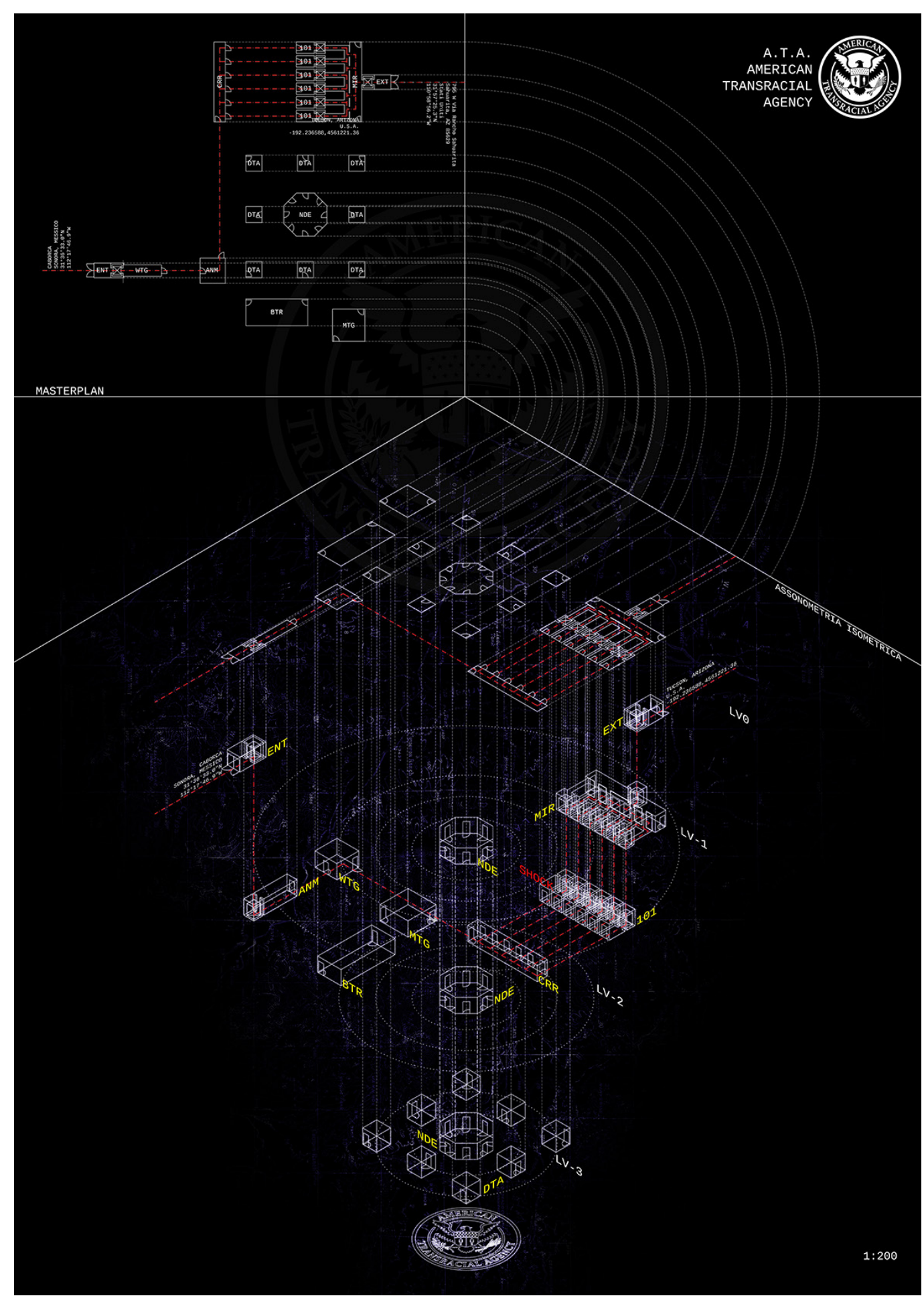


"What is very important is to distinguish two types of writing:
one that I would call writing about architecture
and one that I would call writing of architecture.
Writing about architecture is the most common...
the texts are generally descriptive...
but in themselves they are not architecture...
They are architectures in themselves.
In other words, they propose forms of architectural strategies,
literally in the form of a substitute"

[Tschumi, 1993, pp. 50, 51]

With a similar attitude to understanding the 'representation' of the wall not only as a barrier, but as a real spatial device and therefore a 'place' in which things happen, the American Transracial Agency project moves within a totally imaginary and surreal dimension, proposing to create a 'space' understood as a 'process', first of all conceptual and then physical, consisting of relational devices that in the conceptual 'thickness' of the wall are able - through a subtle play of the absurd - to neutralize the effect of separation and exclusion that it generates and underlies. The 'side effects' of the presence of the wall are, in fact, all contained in the design of a complex underground architecture located near the U.S.- Mexico border and composed of access areas, waiting areas, control areas, rooms with neuronal activators, elevators, entrance paths and exit areas beyond the wall. Elements of a route capable of modifying in real time - and at the request of the interested subject - the 'race' of the person in transit and thus make the barrier set up by the wall ineffective. Everything is described through a tight narrative, and a precise description of the places and actions, generated by the sudden appearance on the computer of the narrator of the '404' archive: a shower of documents, plans, itineraries, conceptual maps, aerial photos that, because of a BUG in the Internet, spread virally, reveal the process in progress and make it clear to the world. The more the narrative pushes the limit of the absurd and science fiction, the more verisimilar and precise the representation of the places is. The more absurd the condition of conflict created by the wall, the more effective and definitive the surreal solution proposed and described with the force of design provocation that finds resonance in the representative choices in which the description of the project takes on the evocative power of a declaration of intent, thanks to the communicative capacity of the image and its staging in the visual presentation of the project that through representation becomes a tale.

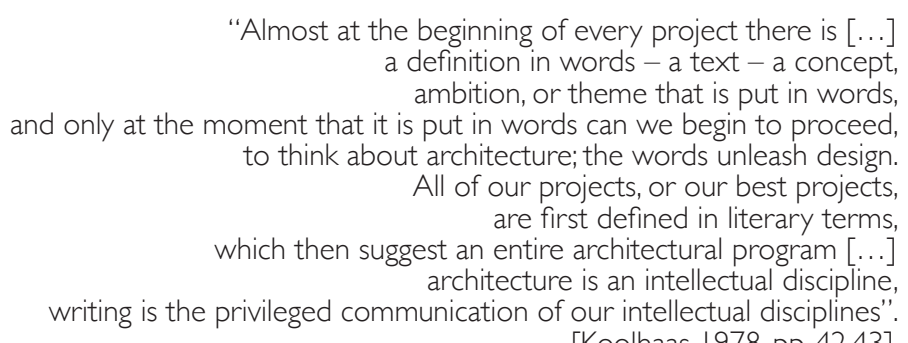

[Koolhaas 1978, pp. 42,43].

\section{Notes}

[I] The thesis in Architecture entitled AMERICAN TRANSRACIAL AGENCY. Conflict Architecture. Side effects, was discussed by Carmine Errico, cum laude and dignity of the press in July 2017 at the Department of Architecture and Industrial Design of the University of Campania 'Luigi Vanvitelli' (thesis supervisor prof. A. Cirafici, co-supervisor prof. F. Ippolito). 
[2] Teddy Cruz, urban architect and professor of Public Culture and Urbanism at the Visual Arts Department of the University of California, San Diego, is internationally renowned for his urban and architectural research on the Tijuana-San Diego border His work aims to interpret borderline immigrant neighborhoods as places of cultural production from which to rethink urban policy, affordable housing and civic infrastructures. His investigation of this 'geography of conflict' has inspired an evocative design practice and pedagogy of design production. On his work and that of Estudio Teddy Cruz + Forman see among others, T. Misra, "The Border Is a Way of Reinforcing Antagonism That Doesn't Exist." Architect Teddy Cruz and political scientist Fonna Forman want to turn the line between the U.S. and Mexico into a site for creative problem solving'. CityLab: <http://www. citylab.com/housing/20 I 7/0 I/the-urban-laboratory-on-the-san-diego-tijuana-border-teddy-cruz-fonna-forman/5 I 2222/>.

[3] Rem Koolhaas and Elia Zenghelis, with Madelon Vriesendorp and Zoe Zenghelis, Exodus, or the Voluntary Prisoners of Architecture: Exhausted Fugitives Led to Reception, 1972.

\section{References}

Davidson Cynthia (1993). Rem Koolhaas:Why I wrote Delirious New York. In ANy 0 | Writing in Architecture, may-june, pp.42, 43.

Foucault Michel (200I). Le jeu de Michel Foucault. Da un'intervista apparsa nel 1977 sotto il titolo Le jeu de Michel Foucault, ristampata in M. Foucault, Dits et Ecrits 1954- 1988, tomo III (1976-1979) Parigi, Gallimard, 2004, testo n² 206 (200 I) pp. 299 300. Davidson Cynthia (1993). Bernard Tchumi: Modes of Inscription. In ANy O | Writing in Architecture, may-june, pp. 50, 5 I.

Davidson Cynthia (1993). Rem Koolhaas:Why I wrote Delirious New York. In ANy O | Writing in Architecture, may-june, pp.42, 43. Koolhaas Rem (1978). Dalì and Le Corbusier:The Paranoid-Critical Method. In Architectural Design, nr. 48, pp. I 52 - I 64.

Koolhaas Rem (1978). Delirious New York. Oxford: Oxford University Press.

Koolhaas Rem, Zenghelis Elia (1972). Exodus. In Casabella, 378, pp. 42-45.

Lambert Leopold (2012). Weaponized Architecture:The Impossibility of Innocence. New York: dpr. Barcelona.

Author

Alessandra Cirafıci, Università degli Studi della Campania “Luigi Vanvitelli”, alessandra.cirafici@unicampania.it

To cite this chapter. Cirafici Alessandra (2020). Muri/effetti collaterali/Walls Side effects. In Arena A., Arena M., Brandolino R.G., Colistra D., Ginex G. Mediati D., Nucifora S. Raffa P. (a cura di). Connettere. Un disegno per annodare e tessere. Atti del $42^{\circ}$ Convegno Internazionale dei Docenti delle Discipline della Rappresentazione/Connecting. Drawing for weaving relationships. Proceedings of the 42th International Conference of Representation Discipline della Rappresentazione/Connecting. Drawing for
Disciplines Teachers. Milano: FrancoAngeli, pp. 3105-3128. 